\title{
RANCANG BANGUN APLIKASI SINGLE SIGN-ON SERVER MENGGUNAKAN AUTENTIKASI GAMBAR
}

\author{
TUGAS AKHIR \\ Diajukan Sebagai Salah Satu Syarat \\ Untuk Memperoleh Gelar Sarjana Teknik Pada \\ Jurusan Teknik Informatika
}

Oleh :

\section{GUNTORO}

10651004298

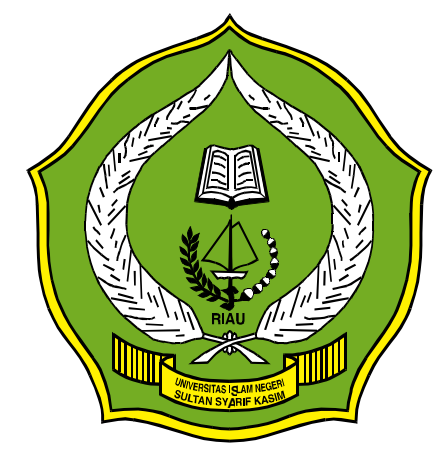

JURUSAN TEKNIK INFORMATIKA

FAKULTAS SAINS DAN TEKNOLOGI

UNIVERSITAS ISLAM NEGERI SULTAN SYARIF KASIM RIAU

PEKANBARU 


\title{
RANCANG BANGUN APLIKASI SINGLE SIGN ON SERVER MENGGUNAKAN AUTENTIKASI GAMBAR
}

\author{
GUNTORO \\ 10651004298 \\ Tanggal Sidang : 19 Mei 2011 \\ Periode Wisuda : Juli 2011 \\ Jurusan Teknik Informatika \\ Fakultas Sains dan Teknologi \\ Universitas Islam Negeri Sultan Syarif Kasim Riau
}

\begin{abstract}
ABSTRAK
Pada tugas akhir ini dikembangkan sebuah aplikasi sistem single sign-on dengan menerapkan autentikasi login menggunakan gambar. Sistem single signon merupakan sebuah teknologi yang mengizinkan pengguna jaringan agar dapat mengakses sumber daya dalam jaringan hanya dengan menggunakan satu akun pengguna saja. Dengan menggunakan single sign-on, seorang pengguna hanya cukup melakukan proses autentikasi sekali saja untuk mendapatkan izin akses terhadap semua layanan yang terdapat di dalam jaringan. Autentikasi login berbasis teks pada sistem single sign-on yang sudah ada saat ini, mempunyai kelemahan, salah satunya adalah pencurian password dengan aplikasi keylogger.

Aplikasi Sistem single sign-on yang dikembangkan dengan menerapkan autentikasi menggunakan gambar. Gambar yang digunakan telah diberikan sebuah keamanan yaitu menggunakan teknik steganografi dengan metode Least Significant Bit.

Sistem single sign-on yang dibangun menggunakan pemrograman PHP. Berdasarkan hasil pengujian sistem single sign-on yang dilakukan dapat dilihat bahwa sistem dapat berjalan dengan baik dan autentikasi gambar dengan menerapkan metode least significant bit dapat diimplementasikan pada sistem login single sign-on.
\end{abstract}

Kata Kunci : Autentikasi, Least Significant Bit, Single Sign-On, Steganografi 


\section{DAFTAR ISI}

Halaman

Lembar Persetujuan ....................................................................................... ii

Lembar Pengesahan ............................................................................................ iii

Lembar Hak Atas Kekayaan Intelektual ........................................................... iv

Lembar Pernyataan ...................................................................................... $\mathrm{V}$

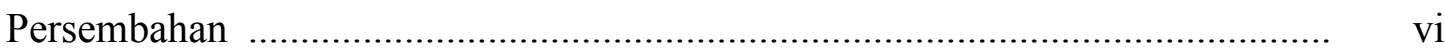

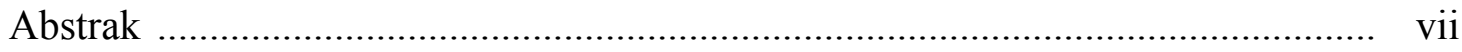

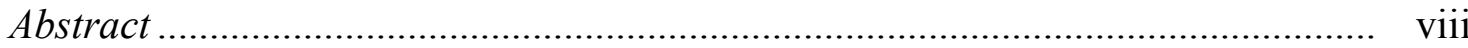

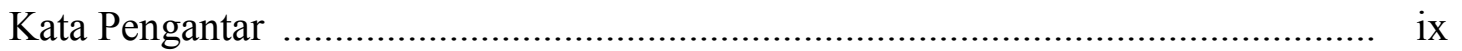

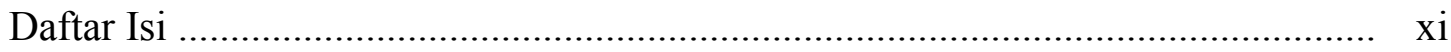

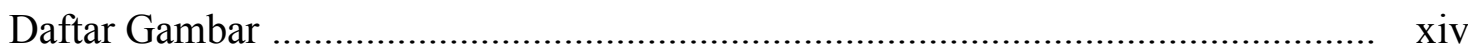

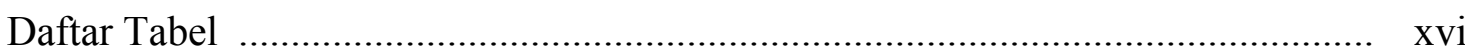

Daftar Lampiran ..................................................................................... $\quad$ xvii

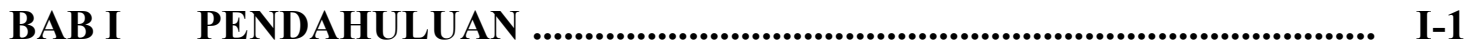

$1.1 \quad$ Latar Belakang .................................................................. I-1

1.2 Rumusan Masalah ...................................................................... I-3

1.3 Batasan Masalah ................................................................. I-3

1.4 Tujuan Penelitian .............................................................. I-3

1.5 Sistematika Penulisan ......................................................... I-4

BAB II LANDASAN TEORI _.............................................................. II-1

2.1 Single Sign-On .................................................................. II-1

2.1.1 Arsitektur Sistem SSO ............................................ II-2

2.1.2 Persyaratan Sistem Single Sign-On ............................... II-4

2.1.3 Produk Sistem Single Sign-On ................................... II-5

2.2 Mekanisme Kerja Protokol TCP/IP ....................................... II-7

2.2.1 Security Lapisan Aplikasi (Application Layer Security) .. II-8

2.2.1 Security Lapisan Transport (Transport Layer Security)... II-8

2.2.1 Security Lapisan Internetwork (IPSec) .......................... II-9 
2.3 Aspek-Aspek Keamanan Komputer ........................................ II-9

2.4 Metode-metode Identifikasi dan Autentikasi ............................. II-10

2.5 Macam-Macam Format Gambar ............................................ II-12

2.6 Steganografi .............................................................. II-13

2.6.1 Metode Steganografi Pada Gambar .............................. II-13

2.6.1.1 Penyisipan Least Significant Bit (LSB) ............ II-13

2.6.1.2 Masking dan Filtering ................................... II-15

2.6.1.3 Tranformation ............................................... II-15

2.7 Web Service ....................................................................... II-17

2.4.1 Definisi Web Service ................................................... II-17

2.4.1 Macam-Macam Web Service …..................................... II-18

2.4.1.1 XML-RPC ................................................. II-18

2.4.1.1 SOAP …................................................ II-18

2.4.1.1 REST ........................................................... II-18

BAB III METODOLOGI PENELITIAN ..................................................... III-1

3.1 Metodologi Penelitian ............................................................. III-1

3.1.1 Perencanaan ........................................................... III-2

3.1.2 Studi Literatur ......................................................... III-3

3.1.3 Analisa dan Perancangan ............................................. III-3

3.1.3.1 Analisa .......................................................... III-3

3.1.3.1 Perancangan ................................................ III-3

3.1.4 Implementasi dan Pengujian ...................................... III

3.1.4.1 Implementasi ............................................... III-4

3.1.4.2 Pengujian .................................................... III-4

BAB IV ANALISIS DAN PERANCANGAN ................................................. IV-1

4.1 Analisa Masalah .................................................................. IV-1

4.1.1 Deskripsi Sistem Single Sign-On ................................... IV-3

4.1.2 Analisa Sistem Single Sign-On ..................................... IV-3

4.1.3 Analisa Proses Otorisasi Sistem Single Sign-On .............. IV-4

4.1.4 Analisa Penyisipan Data Pada Gambar dengan Metode

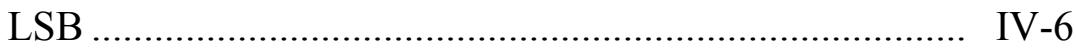


4.1.3 Analisa Penggunaan Web Service REST ........................ IV -8

4.2 Deskripsi Fungsional ............................................................ IV-9

4.2.1 Context Diagram ......................................................... IV-9

4.2.2 Data Flow Diagram ................................................ IV-10

4.2.3 Perancangan Tabel ................................................... IV-11

4.2.4 Perancangan Antar Muka ............................................. IV-11

4.2.4.1 Perancangan Form Registrasi Pengguna ............ IV-11

4.2.4.2 Perancangan Form Steganografi....................... IV-12

4.2.4.3 Perancangan Form Login Single Sign-On ......... IV-13

4.2.4.4 Perancangan Halaman Utama …....................... IV-13

BAB V IMPLEMENTASI DAN PENGUJIAN _......................................... V-1

5.1 Implementasi Sistem ......................................................... V-1

5.1.1 Lingkungan Implementasi .......................................... V-1

5.1.2 Batasan Implementasi …........................................... V-2

5.1.3 Teknis Implementasi Sistem Single Sign-On ................... V-2

5.2 Pengujian Sistem ............................................................... V-3

5.2.1 Lingkungan Pengujian Sistem ...................................... V-3

5.2.2 Pengujian Sistem Single Sign-On ................................. V-5

5.2.3 Pengujian Prosedur Sistem Single Sign-On …................. V-7

5.2.3.1 Pengujian Authentication .................................. V-7

5.2.3.2 Pengujian Strong Authentication ...................... V-8

5.2.3.3 Pengujian Authorization ................................... V-8

5.2.3 Pengujian Keamanan Sistem Single Sign-On .................. V-9

5.2.4 Kesimpulan Pengujian ............................................... V-13

BAB VI PENUTUP ................................................................................. VI-1

6.1 Kesimpulan ............................................................................. VI-1

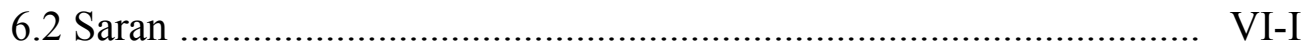

DAFTAR PUSTAKA

LAMPIRAN 


\section{DAFTAR TABEL}

Tabel

Halaman

2.1 Perbandingan Keunggulan Beberapa Produk SSO

II-6

2.2 Perbandingan Kekurangan Beberapa Produk SSO II-6

2.3 Tipe-Tipe Otentikasi II-10

2.4 Kolerasi Method dengan CRUD II-19

4.1 Keterangan Proses Pada DFD Level 1 IV -10

4.2 Pengguna IV-11

5.1 Daftar File Server Single Sign-On $\mathrm{V}-3$

5.2 Daftar File Pada Client Web Portal $\mathrm{V}-3$

5.3 Spesifikasi Aplikasi Pengujian V-9 


\section{BAB I \\ PENDAHULUAN}

\subsection{Latar Belakang}

Otentikasi merupakan suatu proses untuk menentukan apakah seseorang berhak mengakses suatu aplikasi web atau tidak. Cara yang paling sederhana adalah dengan menggunakan proses login, seseorang memasukkan username dan password (credential) kemudian diotentikasi apakah credential tersebut valid atau tidak, jika valid maka seseorang tersebut boleh mengakses, jika tidak maka dia tidak boleh mengakses. Sebagian besar aplikasi web saat ini menggunakan cara tersebut, dengan berbagai tambahan keamanan.

Menjadi suatu masalah ketika seorang pengguna memiliki banyak aplikasi web yang membutuhkan otentikasi. Dia harus menghafal banyak credential, walaupun banyak orang membuat credential yang sama untuk berbagai aplikasi web. Terdapat masalah lagi jika pengguna membuat satu credential untuk berbagai aplikasi web, karena pengguna harus memasukkan credential berulang kali. Misalkan penguna akan menggunakan layanan email maka dia harus memasukkan credential, jika pengguna akan menggunakan layanan forum maka dia harus memasukkan credential dan begitu seterusnya. Oleh karena itu dibutuhkan suatu sistem yang dapat mengintegrasikan seluruh layanan aplikasi dan mengelola proses autentikasi masing-masing sistem layanan, menjadi proses autentikasi. Proses autentikasi pada sistem yang terintegrasi ini memerlukan sebuah sistem tambahan yang menjadi penghubung antara sistem integrator dengan sistem layanan aplikasi. Sistem inilah yang dapat menangani seluruh autentikasi setiap aplikasi sistem, sistem ini dikenal dengan Sistem Single SignOn

Sistem Single Sign-On merupakan sebuah teknologi yang mengizinkan pengguna jaringan agar dapat mengakses sumber daya dalam jaringan hanya dengan menggunakan satu akun pengguna saja. Dengan menggunakan Single Sign-On, seorang pengguna hanya cukup melakukan proses autentikasi sekali saja untuk mendapatkan izin akses terhadap semua layanan yang terdapat di dalam 
jaringan. Autentikasi login berbasis teks pada sistem single sign-on yang sudah ada saat ini, mempunyai kelemahan, salah satunya adalah pencurian password dengan aplikasi keylogger. Oleh karena itu untuk meminimalisir kelemahan tersebut, diterapkan autentikasi berbasis teks dan gambar, yang mana gambar tersebut sudah diberikan keamanan menggunakan steganografi berbasis Least Significant Bit.

Pada penelitian yang berjudul "Open Source in Web-based Applications: A Case Study on Single Sign-On” oleh Agostino dkk (2009), penelitian tersebut mengevaluasi sistem single sign-on berbasis open source menggunakan aplikasi CAS (Central Authentication Service) yang dikembangkan oleh Yale University, SourceID dan JOSSO (Java Open Single Sign-On) serta melakukan perbandingan terhadap ketiga aplikasi single sign-on tersebut. Pada penelitian yang berjudul $A$ Taxonomy of Single Sign-On Systems oleh Pashalidis dkk (2003), membahas tentang pendekatan sistem single sign-on masa depan dalam konteks yang lebih terstruktur, skema sistem single sign-on serta beberapa perbedaan penting dalam hal keamanan sistem single sign-on. Pada Tugas Akhir yang berjudul "Implementasi Sistem Single Sign-On Berbasis Java" oleh Nursyamsi (2009), penelitian tersebut membahas tentang implementasi sistem single sign-on berbasis java dengan menggunakan aplikasi Java Open Single Sign-On (JOSSO).

Sistem single sign-on dengan menerapkan autentikasi menggunakan gambar memiliki beberapa manfaat, salah satunya adalah dengan sistem single sign-on, seseorang pengguna web portal cukup melakukan sekali login untuk beberapa situs web dan autentikasi menggunakan gambar dapat memberikan jaminan Nonrepudiation atau keaslian terhadap gambar yang digunakan. Dengan sistem ini dapat memberikan kemudahan, kenyamanan serta keamanan.

Dari latar belakang diatas maka tujuan pada Tugas Akhir ini adalah bagaimana membangun serta menguji sistem single sign-on dengan menerapkan autentikasi menggunakan gambar. 


\subsection{Rumusan Masalah}

Berdasarkan identifikasi masalah diatas, maka rumusan masalah yang akan disajikan dalam penulisan penelitian ini yaitu bagaimana menganalisa, merancang, membangun serta menguji sistem Single Sign-On dengan menerapkan sistem autentikasi menggunakan gambar.

\subsection{Batasan Masalah}

Dalam pembuatan Tugas Akhir ini mempunyai beberapa batasan masalah diantaranya adalah :

1. Penelitian sistem single sign-on dititikberatkan pada aplikasi berbasis web.

2. Kategori Sistem Single Sign-On yang dibangun berbasis Otorisasi (Authorization)

3. File gambar yang akan digunakan untuk autentikasi telah di sisipi pesan dengan metode steganografi Least Significant Bit (LSB).

4. Tidak membahas ukuran pixel yang digunakan untuk penyisipan kedalam gambar.

5. Metode pengamanan menggunakan file gambar hanya digunakan pada aspek Nonrepudiation.

\subsection{Tujuan}

Tujuan yang ingin dicapai pada Tugas Akhir ini adalah Membangun serta menguji sistem Single Sign-On dengan menerapkan sistem autentikasi menggunakan gambar. 


\subsection{Sistematika Penulisan}

Sistematika penulisan tugas akhir ini dibagi menjadi 6 (enam) bab. Setiap bab terdiri dari sub bab dan penjelasan yang tersusun sehingga mudah untuk dipahami. Berikut penjelasan tentang masing-masing bab:

\section{BAB I Pendahuluan}

Merupakan deskripsi umum dari tugas akhir ini, yang meliputi: latar belakang masalah, rumusan masalah, batasan masalah, tujuan penyusunan tugas akhir serta sistematika penulisan tugas akhir.

\section{BAB II Landasan Teori}

Pada bab ini menjelaskan tentang dasar-dasar yang digunakan untuk penelitian tugas akhir ini antara lain konsep Single Sign On, mekanisme kerja protokol TCP/IP, metode identifikasi dan otentikasi, steganografi, serta web services.

\section{BAB III Metodologi Penelitian}

Dalam bab ini menjelaskan mengenai cara yang dilakukan dalam menyelesaikan persoalan yang menjadi objek penelitian.

\section{BAB IV Analisa dan Perancangan}

Berisi pembahasan mengenai deskripsi kebutuhan sistem dan perancangan komponen.

\section{BAB V Implementasi dan Pengujian}

Berisi pembahasan mengenai lingkungan pengembangan sebuah aplikasi dan hasil pengujian aplikasi.

\section{BAB VI Penutup}

Dalam bab ini akan dijelaskan beberapa kesimpulan yang didapatkan dari Tugas Akhir serta saran untuk penelitian selanjutnya. 


\section{BAB II \\ LANDASAN TEORI}

\subsection{Single Sign-On (SSO)}

Teknologi Single Sign-On (sering disingkat menjadi SSO) adalah teknologi yang mengizinkan pengguna jaringan agar dapat mengakses sumber daya dalam jaringan hanya dengan menggunakan satu akun pengguna saja. Teknologi ini sangat diminati, khususnya dalam jaringan yang sangat besar dan bersifat heterogen (di saat sistem operasi serta aplikasi yang digunakan oleh komputer adalah berasal dari banyak vendor, dan pengguna dimintai untuk mengisi informasi dirinya ke dalam setiap platform yang berbeda tersebut yang hendak diakses oleh pengguna). Dengan menggunakan SSO, seorang pengguna hanya cukup melakukan proses autentikasi sekali saja untuk mendapatkan izin akses terhadap semua layanan yang terdapat di dalam jaringan.(Jani Hursti, 1997) Keuntungan sebuah sistem menggunakan SSO adalah sebagai berikut :

1. Mengurangi tingkat kejenuhan user dalam penggunaan password.

2. Mengurangi waktu yang digunakan untuk memasukkan password kembali untuk sebuah identitas yang sama.

3. Dapat mendukung otentikasi konvensional seperti Windows Credential.

4. Mengurangi biaya IT seiring dengan berkurangnya user yang meminta bantuan mengenai hal otentikasi yang dalam hal ini adalah permasalahan di username atau password.

5. Keamanan di semua level akses baik masuk maupun keluar sistem.

Beberapa kategori sistem single sign-on yaitu :

\section{Autentikasi (Authentication)}

Sistem single sign-on berbasis autentikasi yang mana SSO server hanya memberikan service apakah user A telah ter-autentikasi atau belum, SSO server tidak melakukan proses otorisasi atas user yang sedang aktif tersebut. Proses otorisasi sendiri dilakukan pada setiap aplikasi. Beberapa contoh yang 
menggunakan proses autentikasi adalah OpenID dan fbconnect. OpenID merupakan salah satu yang menggambarkan SSO autentikasi ini. Ketika seseorang akan comment pada suatu blog, kita bisa menggunakan fasilitas OpenID. Dimana OpenID hanya memberitahu wordpress bahwa user telah terautentikasi dan wordpress sendiri bisa mendapatkan data user, seperti nama maupun e-mail. Sama halnya dengan fbconnect, ketika user telah ter-autentikasi pada facebook, maka facebook tidak melakukan otorisasi pada aplikasi client. Jadi hanya sebatas autentikasi.

\section{Otoriasi (Authorization)}

Tugas SSO server untuk SSO-otorisasi memiliki tugas sedikit lebih berat, karena setelah memastikan user telah ter-autentikasi, SSO server masih harus menghandle otorisasi user tersebut.

Sistem single sign-on yang dibangun pada tugas akhir ini adalah berbasis otorisasi (Authorization).

\subsubsection{Arsitektur Sistem SSO}

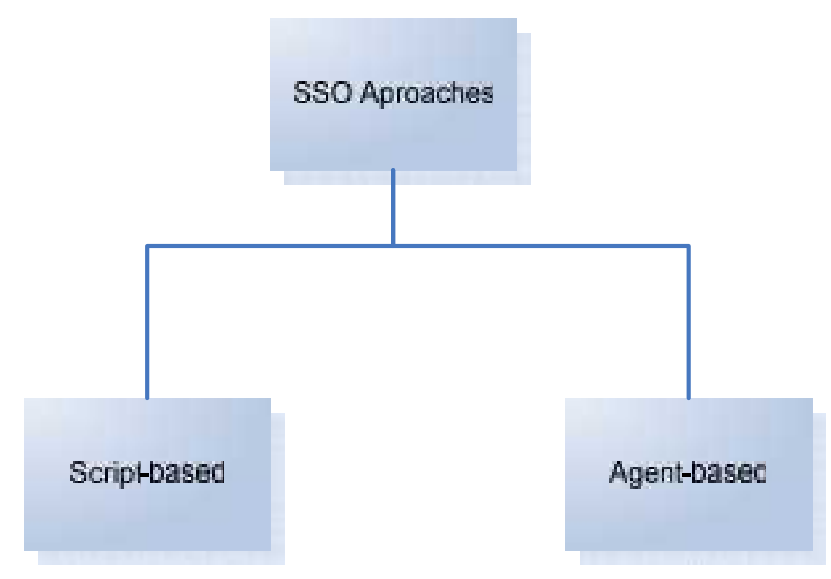

Gambar 2.1 Pendekatan sistem SSO

( Sumber : Springer-Verlag Berlin Heidelberg, 2003 )

Solusi sistem SSO didasarkan pada salah satu dari dua tingkat pendekatanpendekatan script dan pendekatan agent. Pendekatan agent lebih digunakan dalam Tugas Akhir ini karena dianggap lebih cocok untuk aplikasi berbasis web atau 
sevice provider (SP). Gambar 2.1 menunjukkan pembagian dari pendekatan sistem SSO.

Agent merupakan sebuah program kecil yang berjalan pada tiap-tiap web server. Agent ini membantu mengkoordinir aliran kerja dari SSO dalam hal otentikasi pengguna dan penanganan sesi. Solusi dari arsitektur sistem SSO ditunjukkan oleh Gambar 2.2. Arsitektur SSO memiliki dua bagian utama; agent yang berada di web server atau SP dan sebuah server SSO yang berdedikasi yang mana akan dijelaskan berikut ini :

1. Agent : Sebuah agent menterjemahkan setiap permintaan HTTP yang masuk ke web server. Hanya ada satu agent di tiap-tiap web server, yang mana host bagi aplikasi/SP. Agent tersebut akan berinteraksi dengan browser klien pada sisi pengguna, dan dengan server SSO pada sisi SP.

2. SSO server : server SSO menggunakan cookies temporer (sementara) untuk menyediakan fungsi manajemen sesi. Sebuah cookies terdiri dari informasi seperti user-id, session-id, session creation time, session expiration time dan lain-lain.

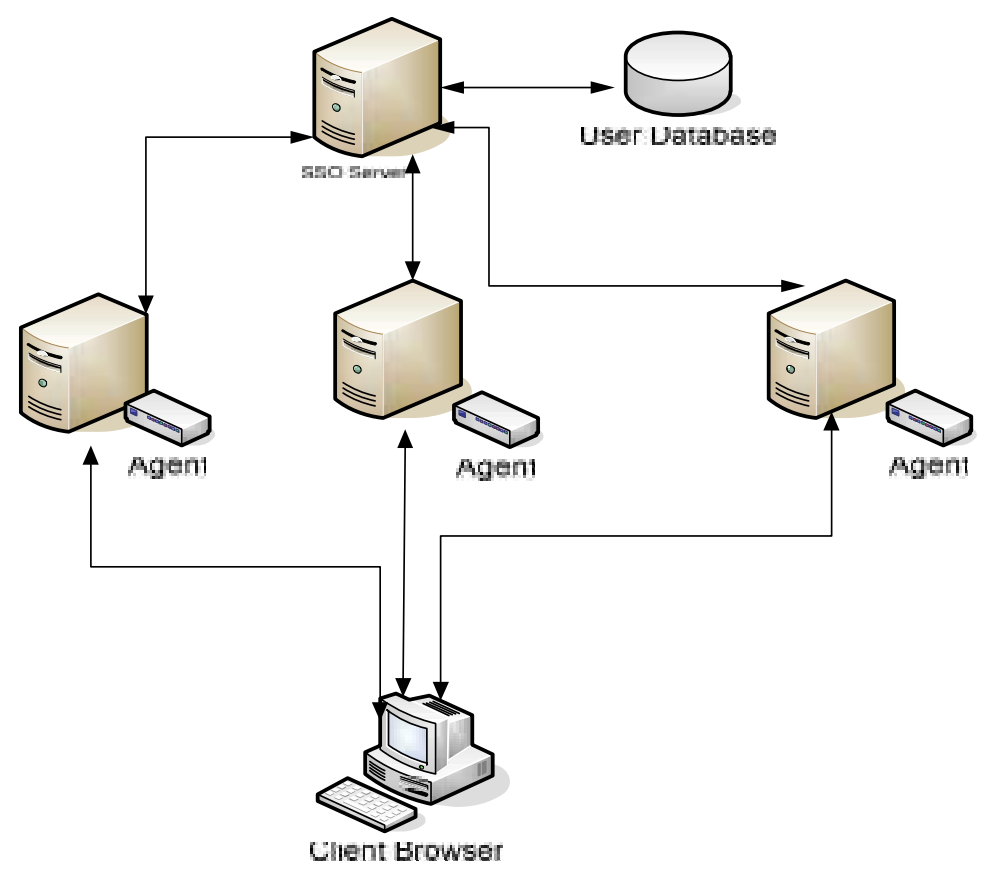

Gambar 2.2 Arsitektur Sistem SSO

( Sumber : Springer-Verlag Berlin Heidelberg, 2003 ) 


\subsubsection{Persyaratan Sistem Single Sign-On}

Beberapa persyaratan dalam membangun sebuah sistem Single Sign-On diantaranya (Ardagna, dkk 2009) yaitu :

\section{Authentication}

Fitur utama dari sistem SSO adalah memberikan suatu mekanisme otentikasi. Biasanya menggunakan otentikasi username dan password.

\section{Strong Authentication}

Untuk keamanan yang lebih tinggi, otentikasi menggunakan username dan password sederhana tidaklah cukup. Solusi utama yaitu menggunakan mekanisme otentikasi berdasarkan biometrik seperti (sidik jari, retina scan dan lain sebagainya).

\section{Authorization}

Setelah sistem otentikasi sudah dapat digunakan. Maka sistem dapat memberikan suatu otorisasi.

\section{Provisioning}

Ketentuan merupakan kondisi yang dibutuhkan sebelum keputusan diambil (Bettini, Jajodia, Sean Wang, \& Wijesekera, 2002). Jadi tanggung jawab user memastikan bahwa permintaan dikirim dengan memuaskan.

\section{Federation}

Federation berkaitan erat dengan tingkat kepercayaan.

\section{C.I.M (Centralized Identity Management)}

\section{Client Status Info}

Sistem arsitektur SSO berarti pertukaran informasi pengguna antara server SSO dan layanan untuk memenuhi otentikasi serta otorisasi.

\section{Single Point of Control}

Tujuan dari implementasi sistem SSO yaitu menyediakan pengontrolan jalur akses yang unik bagi para pengguna.

\section{Standard Compliance}

Protocol - protocol yang digunakan dalam sistem SSO misalnya teknologi X.509 (Public-Key Infrastruktur), untuk security menggunakan SAML serta 
protocol untuk bertukar informasi pada lingkungan yang berbeda seperti SOAP.

\section{Cross-Language Availability}

Teknologi yang digunakan untuk mengembangkan sebuah aplikasi, misalnya penerapan protokol berbasis XML.

\section{Password Proliferation Prevention}

Tingkat keamanan password.

\subsubsection{Produk-Produk SSO}

Produk-produk SSO yang berbasis open source yang umum digunakan saat ini adalah sebagai berikut :

\section{CAS (Central Authentication Service)}

CAS adalah sebuah framework untuk Single Sign-On yang dibuat dengan menggunakan bahasa Java. Konsep kerja CAS sebernarnya menggunakan Ticket Granting dimana ketika pengguna melakukan login, maka pengguna akan diberikan ticket (dalam hal ini tersimpan dalam cookies) yang nantinya akan digunakan untuk melakukan itentikasi pada setiap aplikasi web. Jadi di setiap aplikasi web akan dilakukan pengecekan dari ticket yang telah diberikan oleh CAS tersebut.

\section{OpenSSO (Open Single Sign-On)}

OpenSSO adalah sebuah infrastruktur yang mendukung layanan berbasis identitas, dan implementasi solusi dari Single Sign-On (SSO) transparan serbagai komponen keamanan dalam infrastruktur jaringan. OpenSSO berbasisi pada solusi Identity Management yang dikembangkan oleh Sun.

\section{JOSSO (Java Open Single Sign-On)}

JOSSO adalah sebuah infrastruktur SSO berbasis J2EE dan opensource yang bertujuan untuk menyediakan solusi bagi sentralisasi, netral platform, otorisasi dan otentikasi pengguna. 
Tabel 2.1 merupakan perbandingan keunggulan dan kekurangan beberapa produk SSO tersebut :

Tabel 2.1 Perbandingan keunggulan beberapa produk SSO

\begin{tabular}{|c|c|c|}
\hline CAS & OpenSSO & JOSSO \\
\hline $\begin{array}{l}\text { 1. Terdapat banyak client } \\
\text { libraries untuk } \\
\text { membantu } \\
\text { mengintegrasikan } \\
\text { CAS dengan aplikasi } \\
\text { server } \\
\text { 2. Tampilan dada } \\
\text { halaman login dapat } \\
\text { diganti dikonfigurasi } \\
\text { 3. Dapat untuk } \\
\text { dengan mudah un } \\
\text { mengaktifkan HTTP } \\
\text { 4. Dilengkapi dengan } \\
\text { pligguble untuk } \\
\text { authenticators ulidasi } \\
\text { melakukan } \\
\text { terhadap LDAP, dll } \\
\text { 5. Ukuran file 12 MB }\end{array}$ & 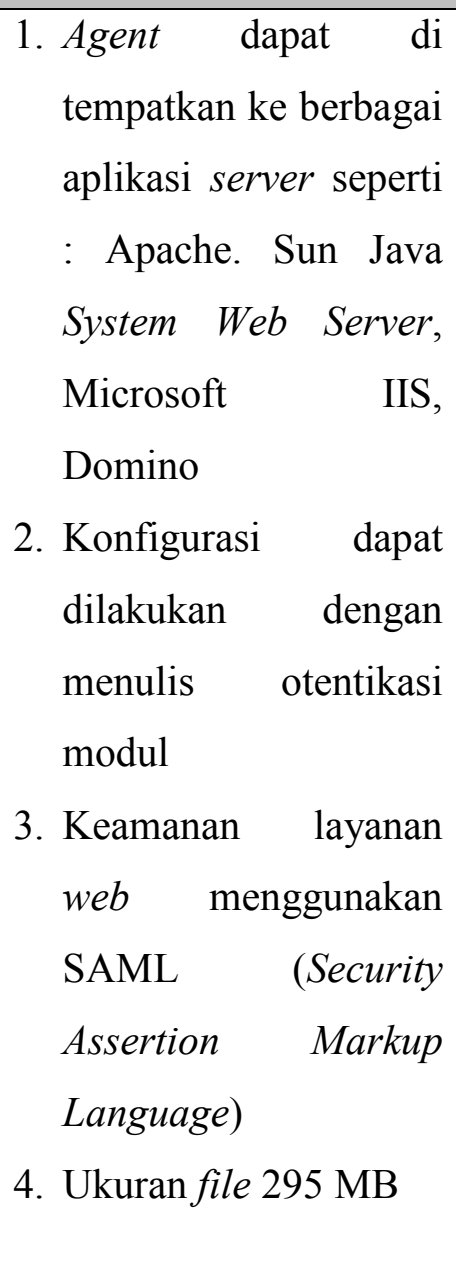 & $\begin{array}{l}\text { 1. Menyediakan sebuah } \\
\text { infrastruktur plugin } \\
\text { untuk berintegrasi } \\
\text { dengan aplikasi server } \\
\text { yang lain } \\
\text { 2. Menggunakan layanan } \\
\text { web untuk menyatakan } \\
\text { identitas pengguna } \\
\text { melalui protokol } \\
\text { SOAP (Simple Object } \\
\text { Access Protokol) } \\
\text { 3. Dapat berintegrasi } \\
\text { dengan aplikasi non } \\
\text { Java (PHP,.Net, dll) } \\
\text { 4. Ukuran file } 45 \text { MB }\end{array}$ \\
\hline
\end{tabular}

Tabel 2.2 Perbandingan kekurangan beberapa produk SSO

\begin{tabular}{|l|l|l|}
\hline \multicolumn{1}{|c|}{ CAS } & \multicolumn{1}{|c|}{ OpenSSO } & \multicolumn{1}{c|}{ JOSSO } \\
\hline Implementasi dasar & Tidak mendukung & Tidak mendukung untuk \\
hanya meliputi HTTPS & $\begin{array}{l}\text { otentikasi proxy tetapi } \\
\text { bisa dibuat sendiri } \\
\text { dengan menggunakan } \\
\text { otentikasi API }\end{array}$ & \\
\hline
\end{tabular}




\subsection{Mekanisme Kerja Protokol TCP/IP}

Transfer Control Protocol/Internet Protocol (TCP/IP) pada dasarnya terdiri dari beberapa protokol yang berbeda, masing-masing dirancang untuk memenuhi tugas-tugas khusus dalam jaringan yang menggunakan TCP/IP. Berkat perinsip ini, tugas masing-masing protokol menjadi jelas dan sederhana. Protokol yang satu tidak perlu mengetahui cara kerja protokol yang lain, sepanjang masih bisa saling mengirim dan menerima data.

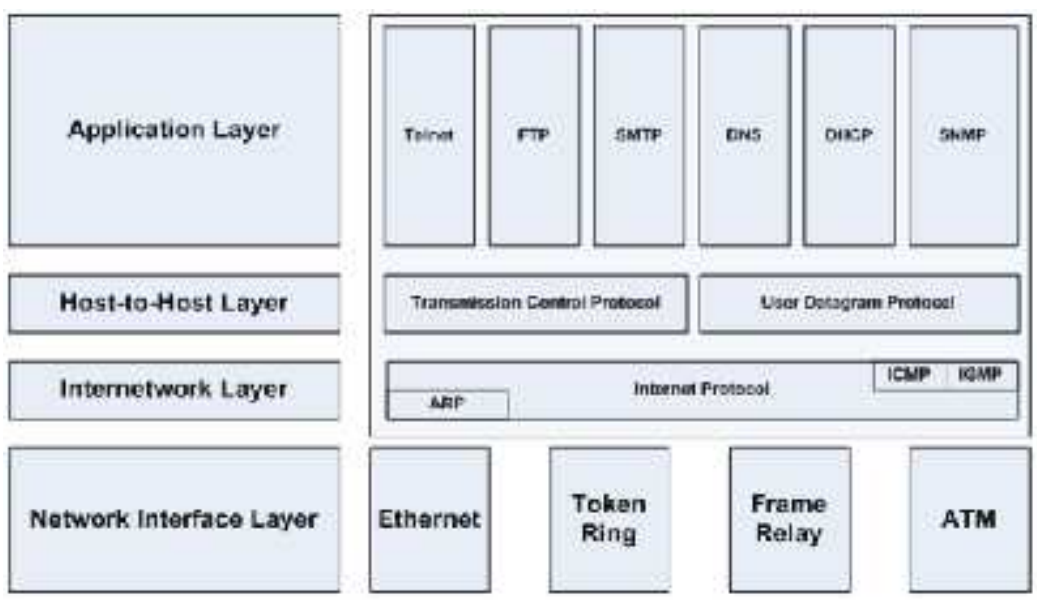

Gambar 2.3 Model Protokol TCP/IP

Oleh karena itu, TCP/IP menjadi protokol komunikasi data yang fleksibel. Protokol TCP/IP dapat diterapkan dengan mudah di setiap jenis komputer dan interface jaringan, karena sebagian besar isi kumpulan protokol ini tidak spesifik terhadap satu komputer atau jaringan tertentu. Agar TCP/IP dapat berjalan diatas interface jaringan tertentu, hanya perlu dilakukan perubahan pada protokol yang berhubungan dengan interface saja.

Model referensi TCP/IP pada gambar 2.3 menunjukkan empat lapisan dalam model TCP/IP yaitu : Network Interface Layer, Internetwork Layer, HostHost Layer/Transport Layer, dan Aplication Layer. Untuk sistem Single Sign On (SSO) ini yang berhubungan dengan protokol otentikasi hanya terdapat pada lapisan/layer Application, Transport dan Internet. Pada setiap lapisan tersebut akan dilihat dari sisi keamanan/security ini dikarenakan sistem otentikasi erat dengan faktor keamanan. 


\subsubsection{Security Lapisan Aplikasi (Application Layer Security)}

Implementasi keamanan pada lapisan aplikasi adalah yang paling mudah dan sederhana, jika komunikasi internet melibatkan dua pihak, seperti kasus komunikasi e-mail dan telnet. Pengirim dan penerima mempunyai kesepakatan untuk menggunakan protokol yang sama dan jenis layanan keamanan yang diinginkan. Pada lapisan ini terdapat 2 protokol yang digunakan, yaitu PGP (Pretty Good Privacy) dan SSH (secure shell).

\subsubsection{Security Lapisan Transport (Transport Layer Security)}

Transport Layer Security (TLS) berada antara lapisan aplikasi dan lapisan transport. Pada Gambar 2.4 diperlihatkan, bahwa TLS berada diantara lapisan protokol HTTP (aplikasi) dan protokol TCP (transport). Dengan demikian dapat dinyatakan bahwa lapisan aplikasi dalam hal ini HTTP menggunakan TLS dan TLS menggunakan layanan dari lapisan transport dalam hal ini TCP untuk membawa informasi.

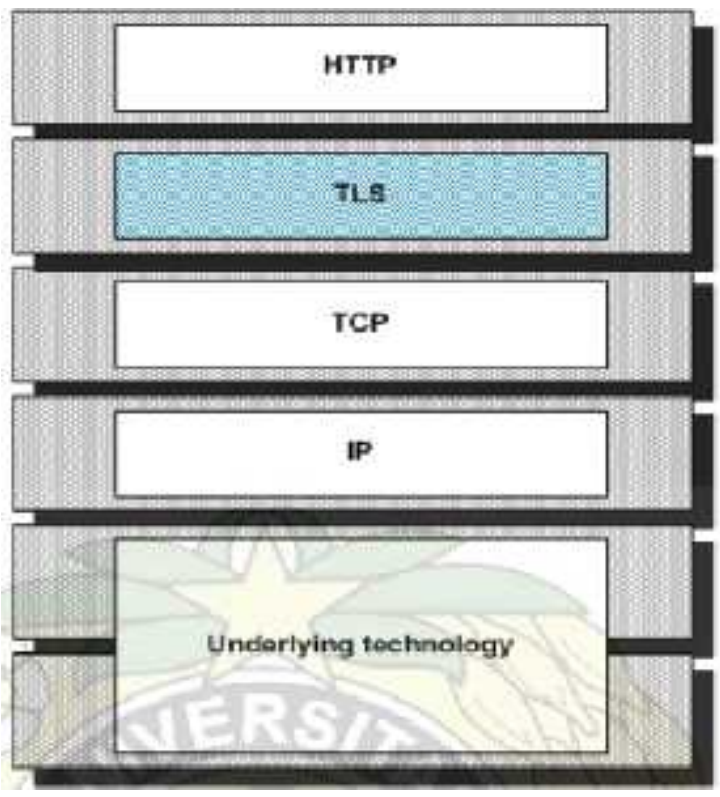

Gambar 2.4 Posisi TLS pada layer-layer protokol IP

TLS dirancang untuk menyediakan keamanan pada lapisan transport. TLS diperoleh dari suatu protokol keamanan yang disebut dengan SSL (Secure Socket 
Layer) yang dirancang oleh Netscape guna menjamin keamanan WWW. TLS adalah bentuk lain dari SSL, yang dirancang oleh IETF (Internet Engineering Task Force) untuk transaksi di internet seperti ditunjukkan pada gambar 2.5.

Secure

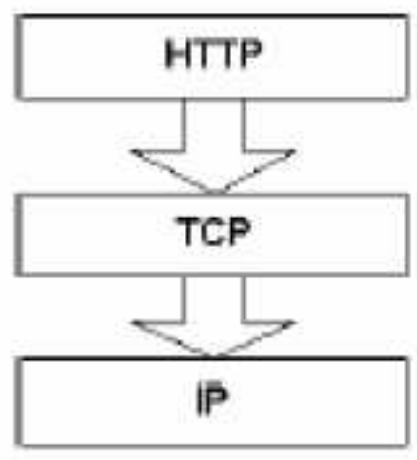

Not Secure

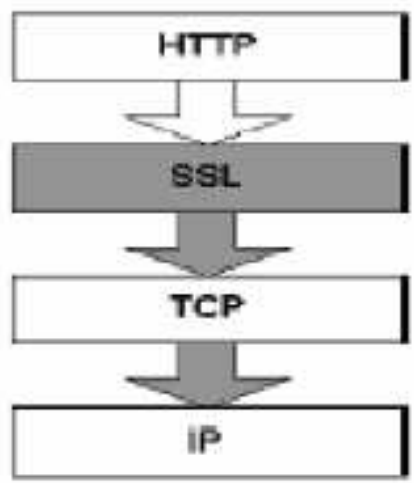

Gambar 2.5 SSL lapisan terpisah dalam susunan protokol Internet

\subsubsection{Security Lapisan Internetwork Layer (IPSec)}

IP Security (IPSec) merupakan sekumpulan protokol yang dirancang oleh IETF (Internet Engineering Task Force) untuk menyediakan layanan keamanan bagi paket data yang dibawa di internet. IPSec tidak didefinisikan untuk menggunakan berbagai metoda enkripsi atau otentikasi yang spesifik. Tetapi IPSec menyediakan sebuah framework dan sebuah mekanisme. IPSec mendefinisikan dua protokol yang digunakan pada IP (lapisan network) seperti : Protokol Authentication Header (AH) dan protokol Encapsulating Security Payload (ESP).

\subsection{Aspek-Aspek Keamanan Komputer}

Keamanan komputer meliputi beberapa aspek di antaranya (Dony Ariyus, 2006) :

1. Authentication : agar penerima informasi dapat memastikan keaslian pesan tersebut datang dari orang yang dimintai informasi. 
2. Integrity : keaslian pesan yang dikirim melalui jaringan dan dapat dipastikan bahwa informasi yang dikirim tidak dimodifikasi oleh orang yang tidak berhak dalam perjalanan informsasi.

3. Nonrepudiation : merupakan hal yang bersangkutan dengan si pengirim. Si pengirim tidak dapat mengelak bahwa dialah yang mengirim informasi tersebut.

4. Authority : Informasi yang berada pada sistem jaringan tidak dapat dimodifikasi oleh pihak yang tidak berhak atas akses tersebut.

\subsection{Metode - Metode Identifikasi dan Otentikasi}

Elemen interface yang pertama kali ditemui kebanyakan subjek ketika mengakses sistem informasi adalah identifikasi dan otentikasi. Tahap identifikasi memperkenankan subjek mengklaim sebagai entitas tertentu dengan menunjukkan bukti-bukti identitas. Bukti-bukti tersebut dapat berupa ID pengguna atau nomor PIN, atau yang lebih kompleks seperti atribut fisik. Setelah subjek mengklaim sautu identitas, sistem memvalidasi apakah pengguna tersebut terdaftar dalam database pengguna dan membuktikan bahwa subjek tersebut adalah benar-benar sebagai entitas yang diklaimnya.

Tahap otentikasi meminta objek menunjukkan informasi tambahan yang sesuai dengan informasi tentang subjek tersebut yang telah disimpan. Dua tahap ini sering disebut dengan otentikasi dua faktor, yang memberikan proteksi terhadap subjek yang tidak memiliki otoritas untuk mengakses sistem. Setelah subjek di otentikasi, sistem kontrol akses mengevaluasi hak dan izin subjek untuk mengabulkan atau menolak permintaan terhadap objek. Tahap ini disebut dengan tahap otoritas.

\section{Tabel 2.3 Tipe-Tipe Otentikasi}

\begin{tabular}{|l|l|l|}
\hline Authentication Type & Description & Examples \\
\hline Type 1 & What you know & $\begin{array}{l}\text { Password, passphrase, } \\
\text { PIN, lock combination }\end{array}$ \\
\hline Type 2 & What you have & Smart card, token device \\
\hline
\end{tabular}




\begin{tabular}{|l|l|l|}
\hline Authentication Type & Description & Examples \\
\hline \hline Type 3 & What you are & $\begin{array}{l}\text { Biometrics, -fingerprint, } \\
\text { palm print, retina/iris } \\
\text { pattern, voice pattern. }\end{array}$ \\
\hline
\end{tabular}

Ada tiga kategori/tipe umum dari informasi otentikasi. Praktek pengamanan yang baik biasanya membuat tahap identifikasi dan otentikasinya memerlukan input setidaknya dari dua tipe berbeda. Tiga tipe umum data otentikasi dijelaskan pada Tabel 2.3.

Tipe otentikasi yang paling umum dan paling mudah untuk diimplementasikan adalah otentikasi tipe 1. Yang dilakukan adalah meminta subjek membuat password, passphrase, atau nomor PIN. Alternatif lain adalah menyediakannya untuk pengguna. Kesulitan dalam otentikasi tipe 1 adalah perlunya mendorong subjek untuk membuat frase yang sangat sulit diterka oleh orang lain, namun tidak terlalu rumit sehingga sulit untuk diingat. Password (frase atau PIN) yang sulit diingat akan mengurangi nilai dari password itu sendiri. Hal tersebut dapat terjadi bila administrator terlalu sering memerlukan penggantian password sehingga pengguna kesulitan untuk mengingat password terbaru. Jadi, yang disarankan adalah menjaga password secara rahasia dan aman. Aturan-aturan berikut ini adalah pentunjuk yang baik untuk membuat password yang aman :

1. Password setidaknya memiliki panjang 6 karakter.

2. Password setidaknya mengandung sebuah angka atau karakter tanda baca.

3. Tidak menggunakan kosakata atau kombinasi kosakata.

4. Tidak menggunakan data pribadi, seperti tanggal kelahiran, nama anggota keluarga atau binatang peliharaan, atau lagu atau hobi favorit.

5. Tidak sesekali menuliskan password.

6. Membuat password yang mudah diingat tapi suit diterka.

Data otentikasi tipe 2 lebih rumit untuk dilakukan karena subjek perlu membawa suatu alat atau sejenisnya. Alat tersebut umumnya perangkat elektronik 
yang menghasilkan suatu nilai yang bersifat sensitif terhadap waktu atau suatu jawaban untuk di input. Meskipun otentikasi tipe 2 lebih rumit, tipe ini hampir selalu lebih aman dibandingkan dengan otentikasi tipe 1.

Otentikasi tipe 3, atau biometrik dalah yang paling canggih. Biometrik menggambarkan pendeteksian dan pengklasifikasian dari atribut fisik. Terdapat banyak teknik biometrik yang berbeda diantaranya :

1. Pembacaan sidik jari/telapak tangan.

2. Geometri tangan

3. Pembacaan retina/iris

4. Pengenalan suara

5. Dinamika tanda tangan

Karena kerumitannya, biometrik adalah tipe otentikasi yang paling mahal untuk diimplementasikan. Tipe ini juga lebih sulit untuk dipeliharan karena sifat ketidak-sempurnaan dari analisis biometerik. Dianjurkan untuk berhati-hati beberapa masalah-masalah utama dari error-error biometrik. Pertama, sistem mungkin menolak subjek yang memiliki otoritas. Ukuran kesalah semacam ini disebut false rejection rate (FRR). Di sisi lain, sistem biometrik mungkin menerima subjek yang salah. Ukuran kesalahan semacam ini disebut dengan false acception rate (FAR). Yang menjadi masalah adalah ketika sensitifitas sistem biometrik diatur untuk menurunkan FRR, maka FAR meningkat. Begitu juga berlaku sebaliknya. Posisi pengaturan yang terbaik adalah bila nilai FRR dan FAR seimbang, ini terjadi pada crossover error rate (CER).

\subsection{Macam-Macam Format Gambar}

Berikut ini adalah macam-macam format file gambar :

1. $\operatorname{BMP}($ Bitmap)

Format file ini merupakan format grafis yang fleksibel untuk platform Windows sehingga dapat dibaca oleh program grafis manapun. Format ini mampu menyimpan informasi dengan kualitas tingkat 1 bit samapi 24 bit. Kelemahan susah dalam pertukaran file. 
2. JPEG (Joint Photographic Experts Group)

Format file sering dimanfaatkan untuk menyimpan gambar yang akan digunakan untuk keperluan halaman web, multimedia, dan publikasi elektronik lainnya.

3. GIF (Graphics Interchange Format)

Format file ini merupakan format standar untuk publikasi elektronik dan internet. Format file mampu menyimpan animasi dua dimensi yang akan dipublikasikan pada internet, desain halaman web dan publikasi elektronik.

4. PNG (Portable Network Graphics)

Format file ini digunakan untuk menampilkan objek dalam halaman web. Kelebihan dari format file ini dibandingkan dengan GIF adalah kemampuannya menyimpan file dalam bit depth hingga 24 bit serta mampu menghasilkan latar belakang (background) yang transparan dengan pinggiran yang halus.

\subsection{Steganografi}

Steganography (covered writing) didefinisikan sebagai ilmu dan seni untuk menyembunyikan pesan rahasia (hiding message) sedemikian sehingga keberadaan (eksistensi) pesan tidak terdeteksi oleh indera manusia.

Media yang digunakan umumnya merupakan suatu media yang berbeda dengan media pembawa informasi rahasia, dimana disinilah fungsi dari teknik steganography yaitu sebagai teknik penyamaran menggunakan media lain yang berbeda sehingga informasi rahasia dalam media awal tidak terlihat secara jelas.

\subsubsection{Metode Steganografi pada Gambar}

Sudah banyak metode yang digunakan untuk menyembunyikan pesan di dalam sebuah image tanpa mengubah tampilan image, sehingga pesan yang disembunyikan tidak akan terlihat. Berikut akan dibahas beberapa metode umum yang digunakan pada image steganography. 


\subsubsection{Penyisipan Least Significant Bit}

Cara paling umum untuk menyembunyikan pesan adalah dengan memanfaatkan Least-Significant Bit (LSB). Walaupun banyak kekurangan pada metode ini, tetapi kemudahan implementasinya membuat metode ini tetap digunakan sampai sekarang. Metode ini membutuhkan syarat, yaitu jika dilakukan kompresi pada stego, harus digunakan format lossless compression, karena metode ini menggunakan bit-bit pada setiap pikses pada image. Jika digunakan format lossy compression, pesan rahasia yang disembunyikan dapat hilang. Jika digunakan image 24 bit color sebagai cover, sebuah bit dari masing-masing komponen Red, Green, dan Blue, dapat digunakan sehingga 3 bit dapat disimpan pada setiap piksel. Sebuah image 800 x 600 piksel dapat digunakan untuk menyembunyikan 1.440 .000 bit (180.000 bytes) data rahasia.

Misalnya, di bawah ini terdapat 3 piksel dari image 24 bit color :

(00100111 1110100111001000$)$

(00100111 1100100011101001$)$

(11001000 0010011111101001$)$

jika diinginkan untuk menyembunyikan karakter A (10000001)

dihasilkan :

(00100111 1110100011001000$)$

(0010011011001000 11101000)

(11001000 0010011011101001$)$

dapat dilihat bahwa hanya 3 bit saja yang perlu diubah untuk menyembunyikan karakter A ini. Perubahan pada LSB ini akan terlalu kecil untuk terdeteksi oleh mata manusia sehingga pesan dapat disembunyikan secara efektif. Jika digunakan image 8 bit color sebagai cover, hanya 1 bit saja dari setiap piksel warna yang dapat dimodifikasi sehingga pemilihan image harus dilakukan dengan sangat hatihati, karena perubahan LSB dapat menyebabkan terjadinya perubahan warna yang ditampilkan pada citra. Akan lebih baik jika image berupa image grayscale karena perubahan warnanya akan lebih sulit dideteksi oleh mata manusia. Proses ekstraksi pesan dapat dengan mudah dilakukan dengan mengekstrak LSB dari masing-masing piksel pada stego secara berurutan dan menuliskannya ke output 
file yang akan berisi pesan tersebut. Kekurangan dari metode modifikasi LSB ini adalah bahwa metode ini membutuhkan tempat penyimpanan yang relatif besar. Kekurangan lain adalah bahwa stego yang dihasilkan tidak dapat dikompress dengan format lossy compression

\subsubsection{Masking dan Filtering}

Teknik masking dan filtering ini biasanya dibatasi pada image 24 bit color atau image grayscale. Metode ini mirip dengan watermark, dimana suatu image diberi tanda (marking) untuk menyembunyikan pesan rahasia. Hal ini dapat dilakukan, misalnya dengan memodifikasi luminance beberapa bagian dari image. Walaupun metode ini akan mengubah tampilan dari image, dimungkinkan untuk melakukannya dengan cara tertentu sehingga mata manusia tidak melihat perbedaannya. Karena metode ini menggunakan aspek image yang memang terlihat langsung, metode ini akan lebih "robust" terhadap kompresi (terutama lossy compression), cropping, dan beberapa image processing lain, bila dibandingkan dengan metode modifikasi LSB.

\subsubsection{Transformation}

Metode yang lebih kompleks untuk menyembunyikan pesan pada image ini dilakukan dengan memanfaatkan Discrete Cosine Transformation (DCT) dan Wavelet Compression. DCT digunakan, terutama pada kompresi JPEG, untuk metransformasikan blok $8 \times 8$ piksel yang berurutan dari image menjadi 64 koefisien DCT. Setiap koefisien DCT F(u,v) dari blok 8x8 piksel image $\mathrm{f}(\mathrm{x}, \mathrm{y})$ dihitung sebagai berikut :

$$
F(u, v)=\frac{1}{4} C(u) C(v)\left[\sum_{x=1}^{7} \sum_{y=1}^{7} f(x, y) * \cos \frac{\langle 2 x+1) w}{16} \cos \frac{2 y+1\rangle v z}{15}\right]
$$

dimana $\mathrm{C}(\mathrm{x})=12$ saat $\mathrm{x}$ sama dengan 0 dengan $\mathrm{C}(\mathrm{x})=1$ saat $\mathrm{x}$ sama dengan 1 . Setelah koefisien-koefisien diperoleh, dilakukan proses kuantisasi sebagai berikut:

$$
F^{2}(u, v)=\left\lfloor\frac{F(u, v)}{Q(u, v)}\right\rfloor
$$


dengan $\mathrm{Q}(\mathrm{u}, \mathrm{v})$ adalah 64-elemen dari tabel kuantisasi. Walaupun image yang dikompresi dengan lossy compression akan menimbulkan kecurigaan karena perubahan LSB akan terlihat jelas, pada metode ini hal ini tidak akan terjadi karena metode ini terjadi di domain frekuensi di dalam image, bukan pada domain spasial, sehingga tidak akan ada perubahan yang terlihat pada cover image. Wavelet Compression adalah salah satu cara kompresi data yang cocok digunakan untuk kompresi image, audio, dan video. Tujuannya adalah untuk menyimpan data dalam "ruang" yang sekecil mungkin dalam sebuah file, karenanya hilangnya informasi tertentu memang sudah diharapkan akan terjadi, kompresi ini merupakan contoh lossy compression. Sama seperti DCT, wavelet compression juga berbasis pada domain frekuensi. Keuntungannya, wavelet compression lebih baik dalam merepresentasikan daerah transien, contohnya image bintang pada langit malam. Artinya, elemen dari data yang transien akan direpresentasikan dalam jumlah informasi yang lebih kecil daripada yang terjadi pada transformasi lain, seperti pada DCT. Kerugiannya, wavelet compression kurang baik digunakan pada data yang bersifat periodik dan smooth. Metode yang dilakukan pada wavelet compression akan dijelaskan sebagai berikut. Pertama-tama, dilakukan wavelet transform yang akan menghasilkan koefisien sesuai dengan jumlah piksel pada image sebagai berikut :

$$
[W \psi f](a, b)=\frac{1}{\sqrt{|a|}} \sum_{-\infty}^{\infty} \psi\left(\frac{x-b}{a} f(x) d x\right)
$$

Koefisien wavelet cjk diperoleh dengan :

$$
c_{j k}=[W \psi f]\left(2^{-j}, k 2^{-j}\right)
$$

dimana $\mathrm{a}=2-\mathrm{j}$ disebut binary dilation atau dyadic dilation, dan $\mathrm{b}=\mathrm{k} 2-\mathrm{j}$ disebut binary position atau dyadic position. Setelah koefien wavelet diperoleh, koefisien ini dapat dikompresi dengan mudah karena informasi terkonsentrasi secara statistik pada beberapa koefisien tertentu saja. Prinsip ini disebut dengan transform coding. Setelah itu, koefisien-koefisien dikuantisasi, baru kemudian diencode dengan entropy encoding atau run length encoding. Proses ekstraksi pesan dengan menggunakan metode transformasi ini dilakukan dengan melakukan 
transformasi pada stego untuk memperoleh koefisien transformasi image. Pilih koefisien yang nilainya lebih kecil dari nilai treshold. Ekstrak bit data yang sesuai dengan koefisien ini dan tulis ke output file yang akan berisi pesan tersebut.

\subsection{Web Service}

\subsubsection{Definisi Web Service}

Web service adalah suatu sistem perangkat lunak yang dirancang untuk mendukung interoperabilitas dan interaksi antar sistem pada suatu jaringan. Web service digunakan sebagai suatu fasilitas yang disediakan oleh suatu website untuk menyediakan layanan (dalam bentuk informasi) kepada sistem lain, sehingga sistem lain dapat berinteraksi dengan sistem tersebut melalui layanan-layanan (service) yang disediakan oleh suatu sistem yang menyediakan web service. Web service menyimpan data informasi dalam format XML, sehingga data ini dapat diakses oleh sistem lain walaupun berbeda platform, sistem operasi, maupun bahasa compiler.

Web service bertujuan untuk meningkatkan kolaborasi antar pemrogram dan perusahaan, yang memungkinkan sebuah fungsi di dalam Web Service dapat dipinjam oleh aplikasi lain tanpa perlu mengetahui detil pemrograman yang terdapat di dalamnya.

Beberapa alasan mengapa digunakannya web service adalah sebagai berikut:

1. Web service dapat digunakan untuk mentransformasikan satu atau beberapa bisnis logic atau class dan objek yang terpisah dalam satu ruang lingkup yang menjadi satu, sehingga tingkat keamanan dapat ditangani dengan baik.

2. Web service memiliki kemudahan dalam proses deployment-nya, karena tidak memerlukan registrasi khusus ke dalam suatu sistem operasi. Web service cukup di-upload ke web server dan siap diakses oleh pihak-pihak yang telah diberikan otorisasi.

3. Web service berjalan di port 80 yang merupakan protokol standar HTTP, dengan demikian web service tidak memerlukan konfigurasi khusus di sisi firewall 


\subsubsection{Macam - Macam Web Service}

\subsubsection{XML-RPC}

XMLRPC adalah akronim dari eXtensible Markup Language - Remote Procedure Call. Sebuah spesifikasi XML yang menjelaskan mengenai mekanisme pemanggilan prosedur jarak jauh dengan menggunakan XML. Bisa dikatakan, XMLRPC adalah salah satu bentuk webservice yang disederhanakan dari standar yang konvensional. Dua sistem yang benar-benar terpisah dan berbeda platform serta lingkungan bisa saling berkomunikasi lewat sarana file XML.

\subsubsection{SOAP}

SOAP (Simple Object Access Protocol) adalah standar untuk bertukar pesan-pesan berbasis XML melalui jaringan komputer atau sebuah jalan untuk program yang berjalan pada suatu sistem operasi (OS) untuk berkomunikasi dengan program pada OS yang sama maupun berbeda dengan menggunakan HTTP dan XML sebagai mekanisme untuk pertukaran data.

SOAP menspesifikan secara jelas bagaimana cara untuk meng-encode header HHTP dan file XML sehingga program pada suatu komputer dapat memanggil program pada pada komputer lain dan mengirimkan informasi, dan bagaimana program yang dipanggil memberikan tanggapan.

SOAP adalah protokol ringan yang ditujukan untuk pertukaran informasi struktur pada lingkup desentralisasi, dan terdistribusi. SOAP menggunakan teknologi XML utuk mendefinisikan rangka kerja pemesanan terekstrensi di mana menyediakan konstruksi pesan yang dapat dipertukarkan pada protokol berbeda. Rangka kerja dirancang bebas dari model pemrograman dan spesifikasi implementasi semantik

\subsubsection{REST}

REST (Representational State Transfer) merupakan sebuah gaya arsitekur untuk membangun suatu web service. Isitilah REST ini sendiri dikenalkan pada tahun 2000 dalam disertasi doctor Roy Fielding. Menurut Wikipedia, web service 
merupakan suatu sistem atau aplikasi yang didesain untuk mendukung transaksi data antar komputer maupun sistem operasi melalui jaringan internet. Konsep terpenting dari REST adalah konsep untuk mengakses suatu resources (sumber informasi) serta metode yang digunakan untuk melakukan pertukaran resources dari client ke server.

Metode yang digunakan untuk melakukan pertukaran resources adalah menggunakan http request method atau umumnya dikenal dengan istilah "verbs". Method tersebut dapat disamakan dengan isitilah CRUD (Create Retrieve Update Delete) pada konsep database. Tabel 2.4 menggambarkan kolerasi antara method dengan konsep CRUD.

\section{Tabel 2.4 Kolerasi Method dengan CRUD}

\begin{tabular}{|c|l|l|l|}
\hline No & Method & CRUD & Penjelasan \\
\hline 1 & Get & Retrieve & Mendapatkan Resource yang diinginkan. \\
\hline 2 & Post & Create & Menginputkan data/resource baru \\
\hline 3 & Put & Update & Melakukan update terhadap resource yang dipilih \\
\hline 4 & Delete & Delete & Menghapus data/resource yang dipilih \\
\hline
\end{tabular}

Pada tugas akhir ini metode steganografi menggunakan Penyisipan Least Significant Bit dan web services REST. 


\section{BAB III \\ METODOLOGI PENELITIAN}

Pada bab ini akan diuraikan kerangka permasalahan dengan singkat dan langkah-langkah yang digunakan untuk membahas permasalahan yang diambil dalam penelitian ini. Pada bab ini juga akan dijelaskan alat dan metode yang digunakan untuk melakukan perencanaan dan mendapatkan spesifikasi kebutuhan perangkat lunak yang akan dibuat. Kerangka yang diusulkan diharapakan mampu memandu secara bertahap dari pengembangan penelitian dan memberikan sebuah solusi permasalahan untuk mencapai sasaran akhir dari penelitian ini.

\subsection{Metodologi Penelitian}

Metodologi penelitian merupakan dasar untuk memastikan bahwa semua langkah-langkah dan kegiatan penelitian lebih sistematis. Selain itu, metodologi penelitian mampu menentukan apakah penelitian akan berjalan dengan baik sehingga menghasilkan produk yang sesuai dengan tujuan penelitian ini.

Untuk mendapatkan informasi mengenai sistem single sign-on menggunakan autentikasi gambar, akan dilakukan beberapa pengamatan. Metodologi yang dibutuhkan untuk pengembangan penelitian mulai dari perencanaan, studi literatur, analisa dan perancangan, serta implementasi dan pengujian. 


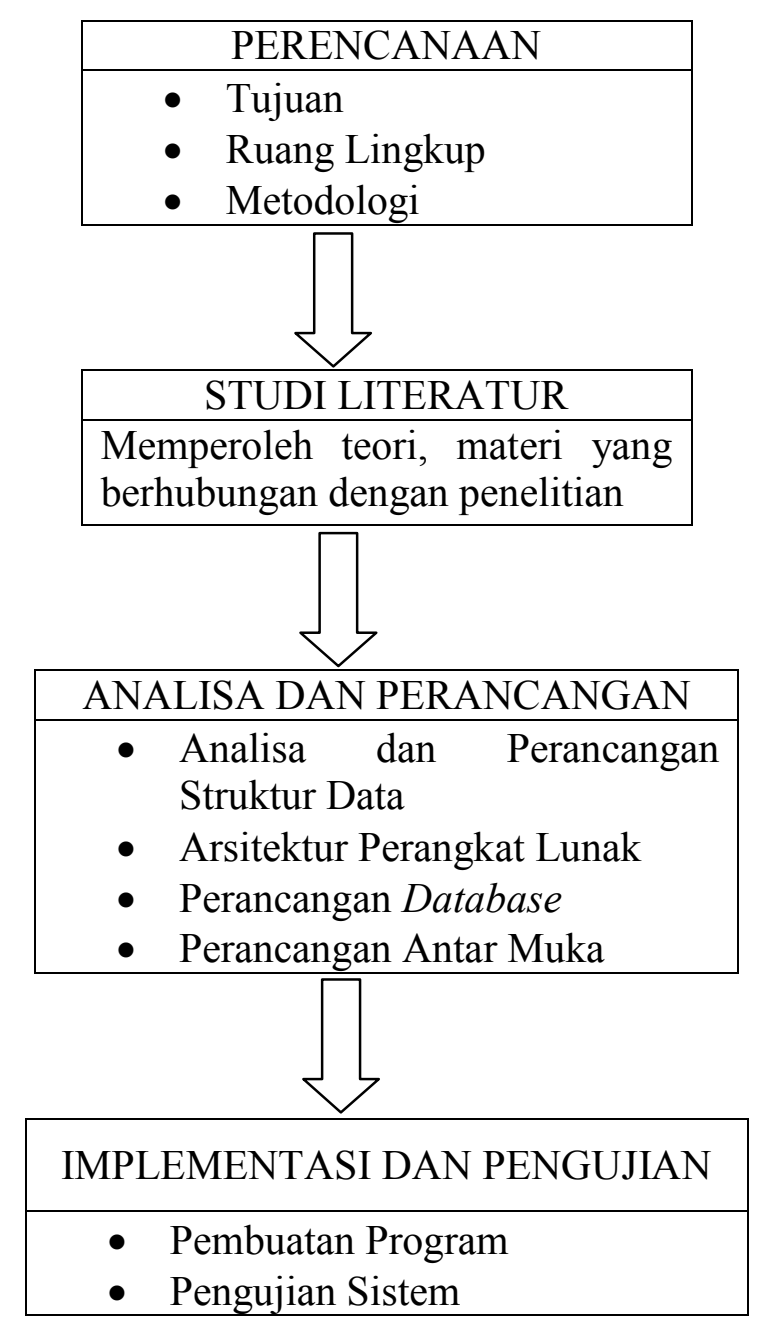

\section{Gambar 3.1 Tahapan Metodologi Penelitian}

\subsubsection{Perencanaan}

Tahap perancanaan merupakan tahap awal dari suatu penelitian. Pada tahap ini dilakukan serangkaian kegiatan yaitu mendiskusikan penelitian yang akan dibahas dengan para pakar yang berkompeten, menganalisa sasaran dari pengembangan penelitian dan digambarkan berdasarkan permasalahan yang ada.

Berikutnya mempelajari ruang lingkup penelitian untuk diberikan batasabatasan pengembangan penelitian, kemudian dapat ditentukan metodologi dari penelitian tersebut. 


\subsubsection{Studi Literatur}

Dimaksudkan untuk memperoleh teori-teori dan konsep-konsep yang mendasar mengenai materi yang berhubungan dengan sistem single sign-on, konsep Steganografi Least Significant Bit. Materi di peroleh dari buku-buku, artikel-artikel di internet, jurnal, serta makalah.

\subsubsection{Analisa dan Perancangan}

\subsubsection{Analisa}

Analisa dilakukan setelah data yang dikumpulkan telah lengkap, analisa ini menjabarkan beberapa data pendukung serta membahas dan menyelesaikan permasalahan-permasalahan yang akan diterapkan untuk membangun sistem. Adapun analisa yang dilakukan diantaranya yaitu :

1. Analisa sistem Single Sign-On, serta proses otorisasi sistem

2. Analisa proses metode Least Significant Bit yang akan digunakan untuk pengamanan gambar.

3. Analisa penggunaan web service REST

Pada saat menganalisa data, ada beberapa tahap yang harus dilakukan, yaitu mengidentifikasi kebutuhan sistem, fungsi sistem, memodelkan sistem dalam bentuk flowchart dan DFD.

\subsubsection{Perancangan}

Setelah tahap analisa selesai maka tahap selanjutnya mulai merancang sistem Single Sign-On. Pada tahap perancangan ini hal yang dilakukan adalah , arsitektur sistem Single Sign-On, membangun antarmuka sistem Single Sign-On, struktur database.

\subsubsection{Implementasi dan Pengujian}

Tahap terakhir yaitu pembuatan sistem berdasarkan analisa yang telah dilakukan atau mengimplementasikan. Selanjutnya dilakukan pengujian terhadap sistem yang telah dibangun agar dapat diketahui hasilnya. 


\subsubsection{Impementasi}

Tahap implementasi merupakan tahap penulisan kode program berdasarkan analisa dan perancangan yang telah dilakukan. Bahasa pemrograman yang digunakan untuk membangun sistem adalah PHP dengan database MySQL.

\subsubsection{Pengujian}

Tahap pengujian yang dilakukan yaitu dengan menguji sistem single signon apakah sistem berjalan sesuai dengan yang diharapkan, serta menguji tingkat keamanan sistem dengan menggunakan aplikasi Keylogger dan Wireshark. 


\section{BAB IV}

\section{ANALISA DAN PERANCANGAN}

Bab ini berisikan penjelasan tentang analisis dan perancangan. Subbab analisis berisi penjelasan tentang hasil analisis yang dilakukan dalam Tugas Akhir. Subbab perancangan berisi berisi penjelasan tentang hasil perancangan perangkat lunak yang dilakukan dalam Tugas Akhir.

\subsection{Analisa Masalah}

Masalah utama dari tugas akhir ini adalah bagaimana membangun sebuah sistem yang dapat melakukan login hanya sekali pada banyak aplikasi web. Pada subbab berikutnya akan dibahas deskripsi sistem single sign-on yang akan dibangun, analisis sistem single sign-on dan bagaimana proses login sistem single sign-on serta analisis penyisipan gambar dengan least significant bit.

\subsubsection{Deskripsi Sistem Single Sign On}

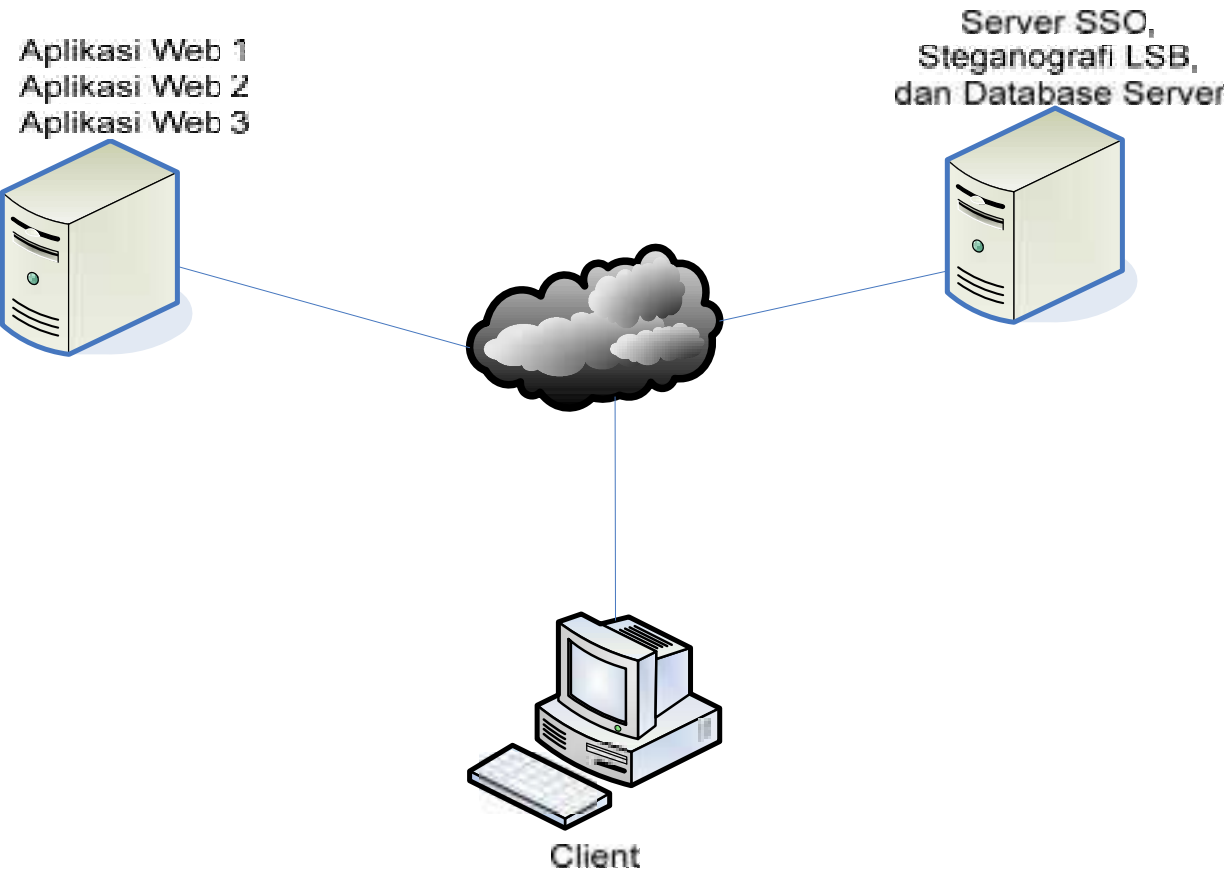

Gambar 4.1 Deskripsi Sistem Single Sign On 
Pada Gambar 4.1 merupakan deskripsi sistem single sign-on yang akan dibangun. Topologi sistem single sign-on terdapat tiga bagian diantaranya adalah :

1. Server sistem single sign-on

Server sistem SSO atau Identity Provider berfungsi menyediakan layanan autentikasi kepada pengguna/client yang membutuhkan autentikasi melalui aplikasi web. Pada sistem single sign-on tersebut, terdapat autentikasi tambahan yaitu autentikasi dengan gambar (Least Signficant Bit).

2. Aplikasi Web 1, Aplikasi Web 2, Aplikasi Web 3

Pada bagian ini merupakan client dari server SSO (aplikasi web) yang mana permintaan autentikasi diberikan kepada pengguna dan mengelola seluruh aliran autentikasi pengguna. Client SSO memvalidasi SSO sesi dan memperoleh informasi pengguna terkait dengan layanan web server SSO dengan menggunakan protokol REST

3. Client (Pengguna)

Seluruh server tersebut terkoneksi oleh jaringan, yang dapat dilihat pada gambar 4.1.

\subsubsection{Analisa Sistem Single Sign-On}

Model kerja sistem yang akan dibangun dapat digambarkan pada flowchart sebagai berikut

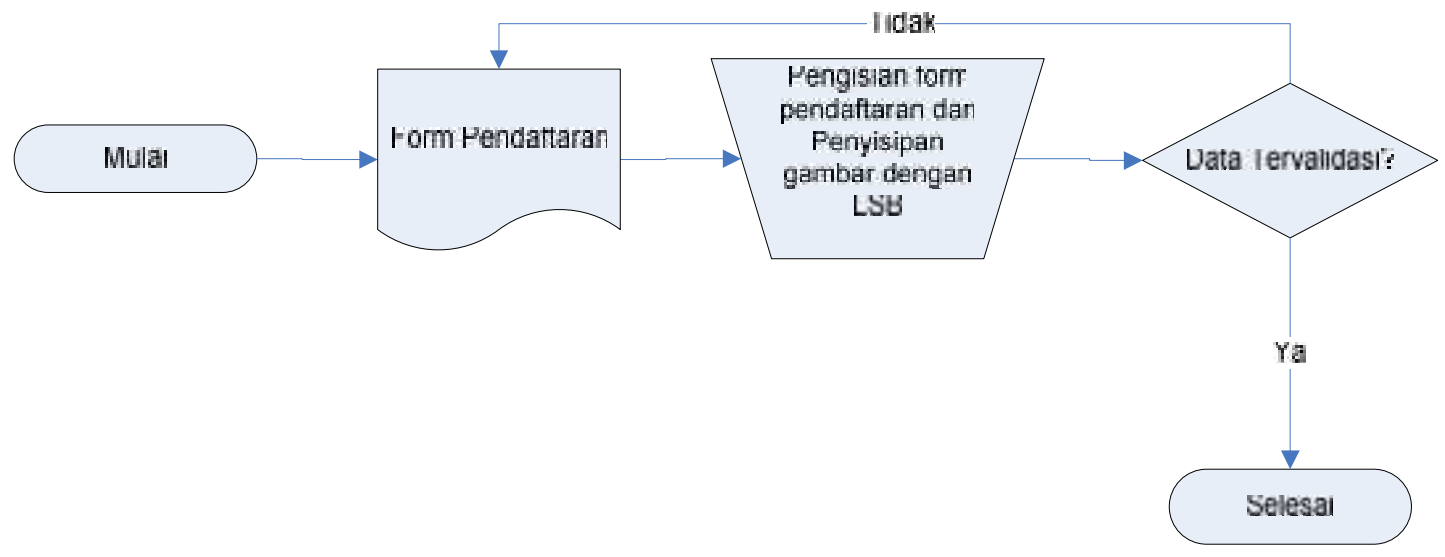

Gambar 4.2 Diagram Alir Pendaftaran Single Sign-On 
Gambar 4.2 merupakan alir sistem pendaftaran pengguna baru, dimana seorang pengguna melakukan pendaftaran terlebih dahulu sebelum dapat mengakses sistem single sign-on, agar mendapatkan account. Calon member mengisi form pendaftaran serta melakukan penyisipan gambar, yang akan digunakan untuk autentikasi login.

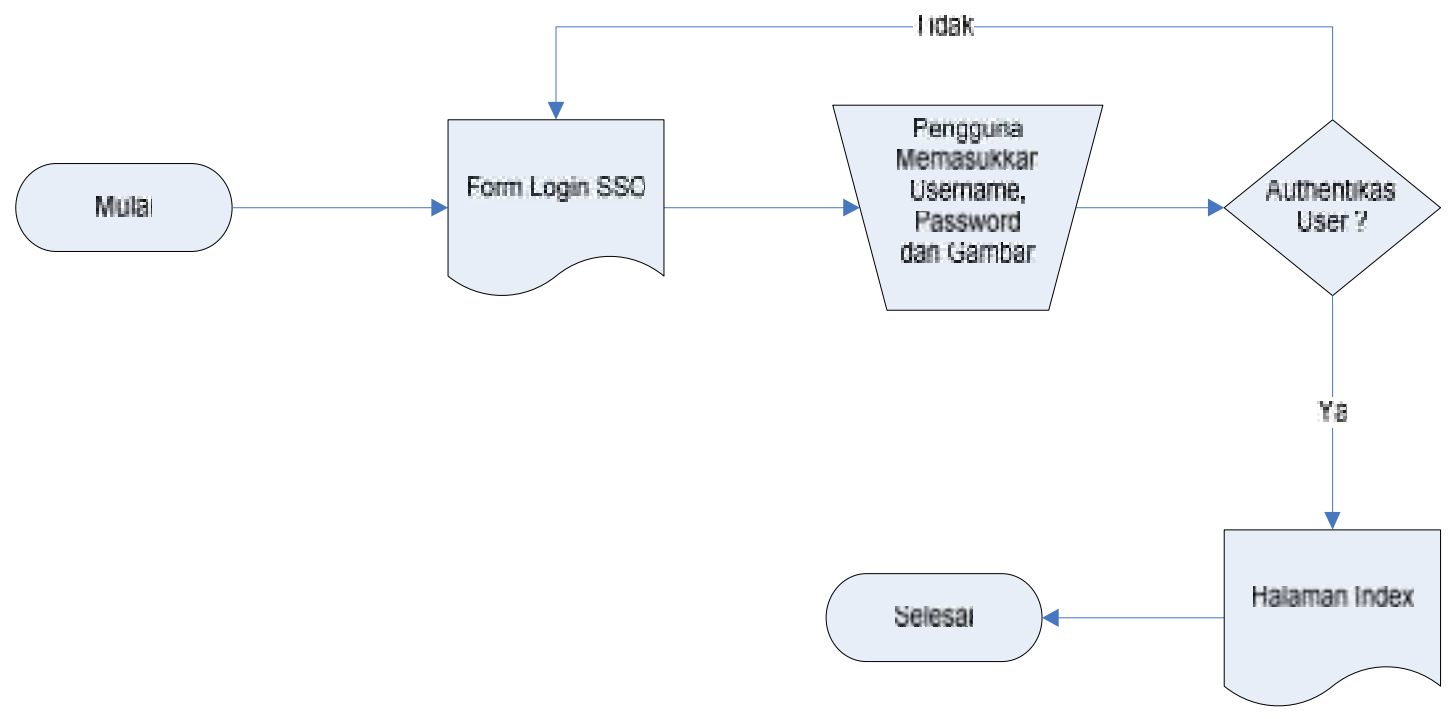

Gambar 4.3 Diagram Alir Login Sistem Single Sign-On

Gambar 4.3 merupakan alur sistem single sign-on yang akan dibangun nantinya. Seorang member mengakses sebuah situs web, dan melakukan login, maka secara otomatis akan dibawa ke halaman Sistem single sign-on Server. Member memasukkan username, password dan file gambar. Jika data member terdaftar pada server maka login akan berhasil. Jika data member tidak terdaftar maka akan dikembalikan lagi ke halaman login single sign-on. Pada proses login, autentikasi dengan gambar melakukan perbandingan antara gambar yang ada di server dengan gambar yang dimasukkan member pada saat login.

Gambar yang digunakan sebagai autentikasi sebelumnya telah disisipi text yaitu menggunakan Metode Least Significant Bit. Untuk analisis penyisipan data pada gambar dengan menggunakan metode Least Significant Bit akan di jelaskan pada 4.1.4. 
Sistem Single sign-on yang dibangun kali ini yaitu berbasiskan Otorisasi, karena sistem single sign-on ini diperuntukkan hanya pada satu lingkungan organisasi, yang mana prosesnya akan di jelaskan pada 4.1.3.

\subsubsection{Analisa Proses Otorisasi Sistem Single Sign-On}

Pada subbab ini akan dijelaskan bagaimana proses otorisasi pada sistem single sign-on yang akan dibangun. Pada sistem single sign-on ini terdapat tiga pihak yaitu :

1. Client adalah pengunjung situs web

2. Aplikasi Web adalah situs web yang dikunjungi

3. Server SSO

Berikut ini adalah gambaran proses login sistem single sign-on:

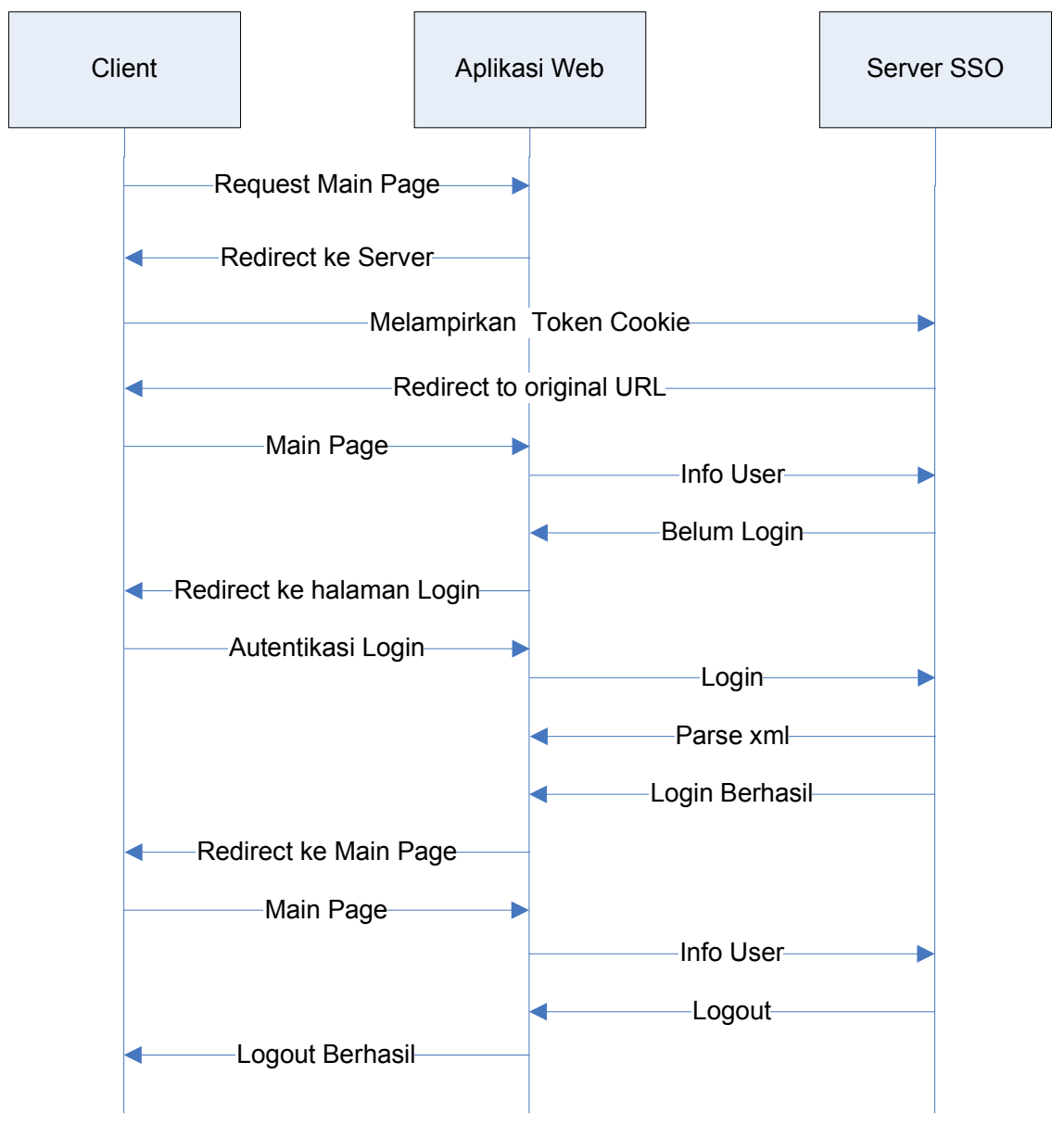

Gambar 4.4 Proses Login Sistem Single Sign-On 
Dari gambar 4.4 dapat dijelaskan, ketika klien mengunjungi sebuah aplikasi web, disaat itu akan diperiksa apakah token cookie sudah ada pada browser. Berikut adalah contoh pseudocode :

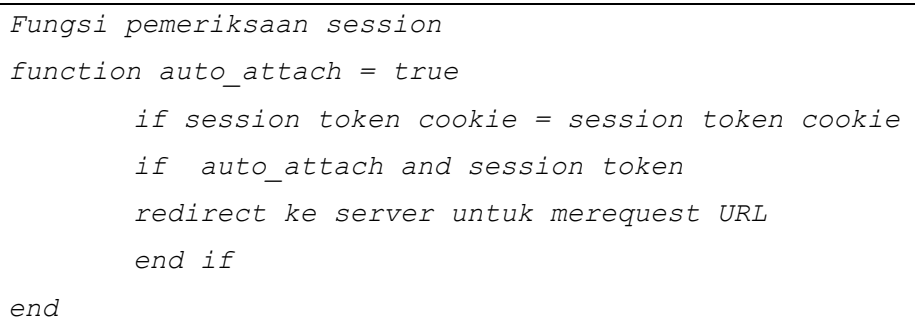

\section{Algoritma 4.1 Fungsi Pemeriksaan Session}

Jika belum ada, maka aplikasi web melakukan redirect ke server SSO dengan memberikan perintah untuk melampirkan sebuah session dan menetapkan identitas aplikasi web. URL token akan diacak dan token disimpan kedalam cookie. Server SSO akan menghasilkan session key berdasarkan aplikasi web, identitas aplikasi web dan token ini disimpan pada sesi klien/browser. Session key berisikan sebuah enkripsi MD5, sehingga seorang hacker tidak dapat mengetahui session tersebut. Berikut adalah contoh enkripsi session ke MD5.

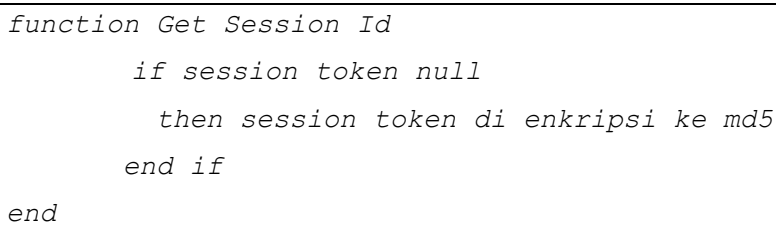

Algoritma 4.2 Fungsi Enkripsi Session ke MD5

Server akan me-redirect klien kembali ke URL aslinya. Setelah ini, klien dapat berkomunikasi dengan aplikasi web. Ketika klien mengakses aplikasi web, server akan merespon kepada aplikasi web bahwa pengunjung sedang tidak login, maka akan langsung di-redirect ke halaman login. Disini klien melakukan login dengan memasukkan username, password dan gambar, aplikasi web akan mengirimkan data tersebut ke server dengan melewati session key. Berikut adalah contoh pseudocode :

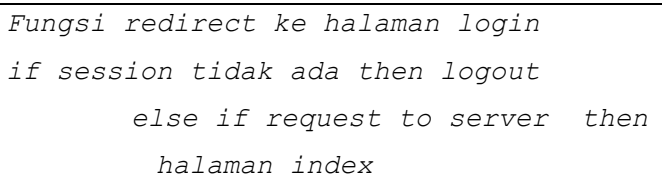




end if
end

\section{Algoritma 4.3 Fungsi Redirect Halaman Login}

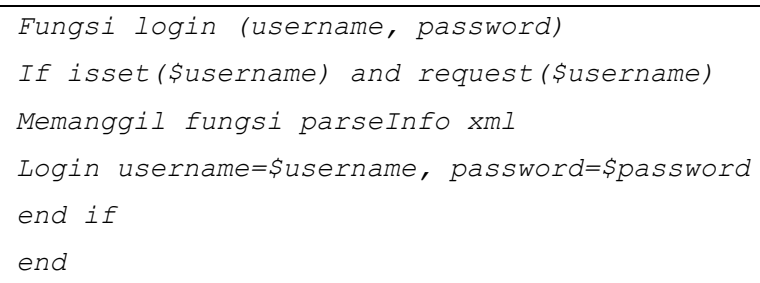

\section{Algoritma 4.4 Fungsi Login}

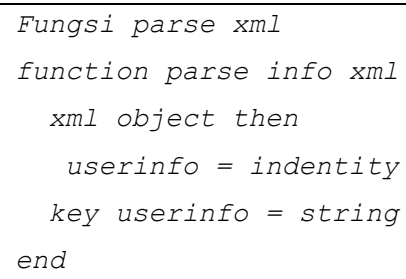

Algoritma 4.5 Fungsi Parse XML

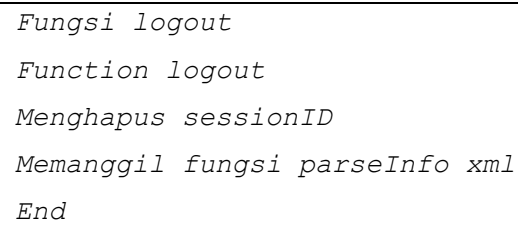

\section{Algoritma 4.6 Fungsi Logout}

Jika data tesebut benar maka server akan mengembalikan ke aplikasi web bahwa login berhasil, begitu sebaliknya ketika client (member) melakukan logout pada salah satu aplikasi web, secara otomatis aplikasi web yang lain akan logout dengan sendirinya tanpa perlu logout untuk kedua kalinya.

\subsubsection{Analisa Penyisipan Data Pada Gambar dengan Metode Least Significant Bit}

Tahap embedding atau penyisipan gambar, dimulai dengan mengubah citra digital yang tersusun atas pixel dengan menggunakan sinyal RGB (Red, Green Blue), menjadi raster data (bilangan biner) untuk menyisipkan pesan dalam informasi. 
Kemudian bilangan biner dalam setiap pixel diambil bit rendah yaitu 1 bit terakhir dari sinyal Blue. Untuk pesan rahasia bertipe karakter akan diubah menjadi bilangan desimal yang kemudian akan diubah menjadi bit pesan (bilangan biner).

Penyisipan data atau pesan dilakukan dengan mengganti setiap bit rendah pada gambar dengan bit pesan. Jika bit rendah kurang dari bit pesan, maka raster ditambah 1. Jika bit rendah lebih besar dari bit pesan, maka raster data dikurang 1 . Jika bit rendah sama dengan bit pesan, maka raster tidak dirubah.

Setelah itu dilakukan penyusunan kembali pixel yang sebelumnya telah disisipi bit pesan sesuai dengan raster data.

Pada gambar 4.5 merupakan metode penyisipan data ke dalam gambar :

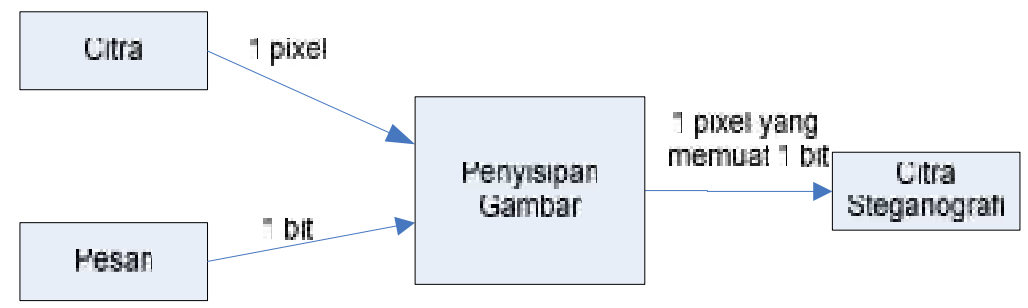

Gambar 4.5 Metode Sisip

Untuk membentuk tahap embedding di perlukan sebuah fungsi sehingga data yang di peroleh dapat disisipkan kedalam file pembawa. Fungsi yang digunakan yaitu fungsi write ( file citra) dan fungsi read ( penyisipan pesan dalam gambar).

Berikut contoh pseudocode Least Significant Bit yang digunakan :

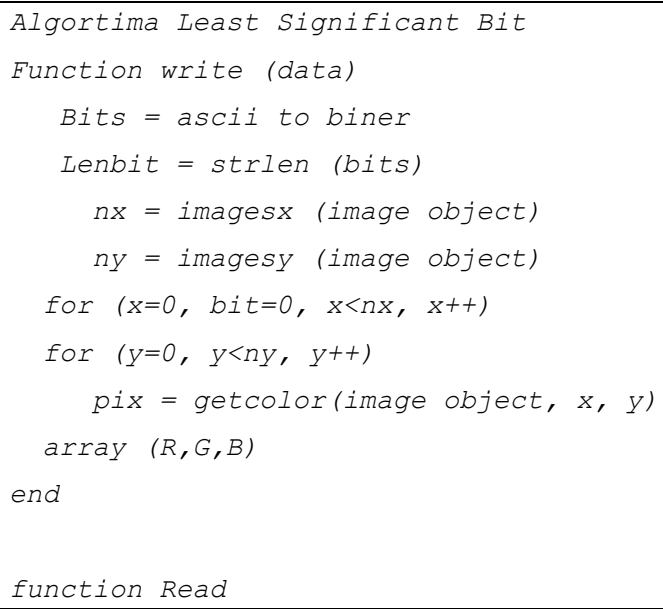




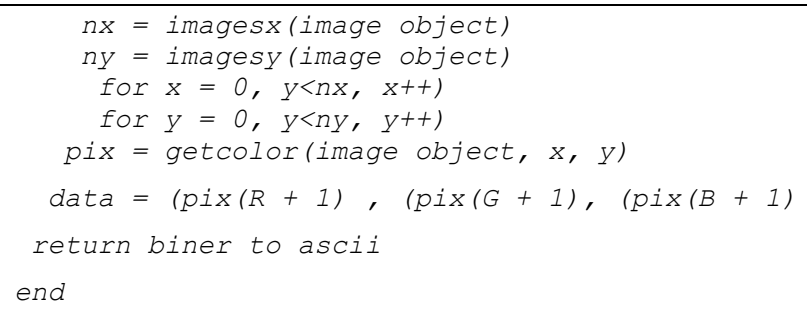

Algoritma 4.7 Algoritma Least Significant Bit

Dari algoritma 4.7 maka cover carrier dapat disisipkan pesan dan menghasilkan gambar steganografi dengan tidak menurunkan tingkat kualitas gambar setelah disisipi, Pada analisa tersebut penggunaan gambar berformat PNG lebih kompatibel, karena perbandingan antara file asli dengan file setelah di lakukan steganografi, tidak memiliki banyak perubahan. Oleh karena itu format PNG tersebut digunakan sebagai autentikasi sistem single sign-on pada tugas akhir ini.

\subsubsection{Analisa Penggunaan Web Service REST}

REST (Representational State Transfer) web service adalah salah satu cara pendistribusian data yang populer saat ini antara server dan client, dengan menggunakan protokol HTTP. Alasan menggunakan web service REST adalah REST mudah dipelajari karena aplikasi web hanya perlu menggunakan koneksi HTTP ke URL tertentu dan tidak tergantung pada aturan $X M L$, web service REST lebih digunakan pada browser dibandingkan dengan web service lainnya. Pada REST, metode HTTP yang digunakan diantaranya :

1. POST untuk membuat sumberdaya (resource) pada server.

2. GET untuk menerima sumberdaya.

3. PUT untuk merubah atau memperbaharui sumberdaya

4. DELETE untuk menghapus sumberdaya. 


\subsection{Deskripsi Fungsional}

Aliran informasi yang ditransformasikan pada saat data bergerak dari Input menjadi output dapat dilihat di Context Diagram dan Data Flow Diagram (DFD)

\subsubsection{Context Diagram}

Diagram konteks (Context Diagram) digunakan untuk menggambarkan hubungan input/output antara sistem dengan dunia luarnya (kesatuan luar) suatu diagram kontek selalu mengandung satu proses, yang mewakili seluruh sistem. Sistem Single Sign-On memiliki entitas yaitu pengguna.

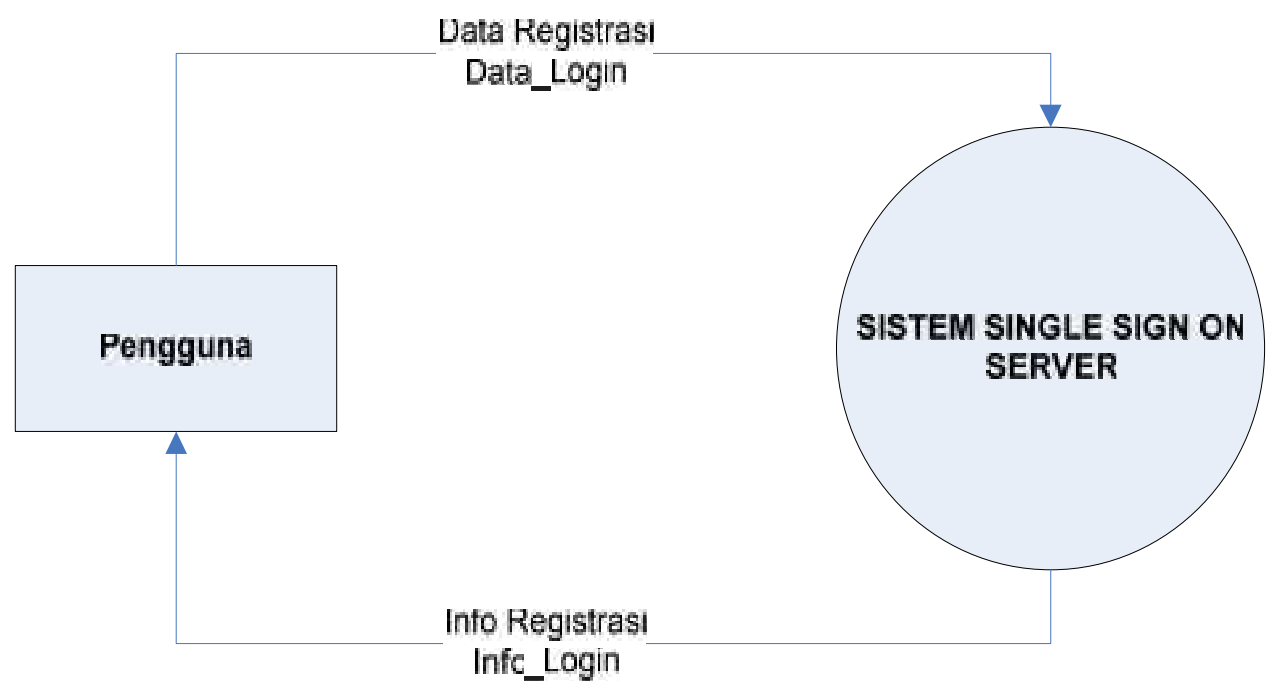

Gambar 4.6 Context Diagram

Entitas luar yang berinteraksi dengan sistem adalah Pengguna yang terdiri dari Input Data Registrasi dan Input Data Login 


\subsubsection{Data Flow Diagram}

Data Flow Diagram (DFD) digunakan untuk menggambarkan suatu sistem yang telah ada atau sistem baru yang akan dikembangkan secara logika.

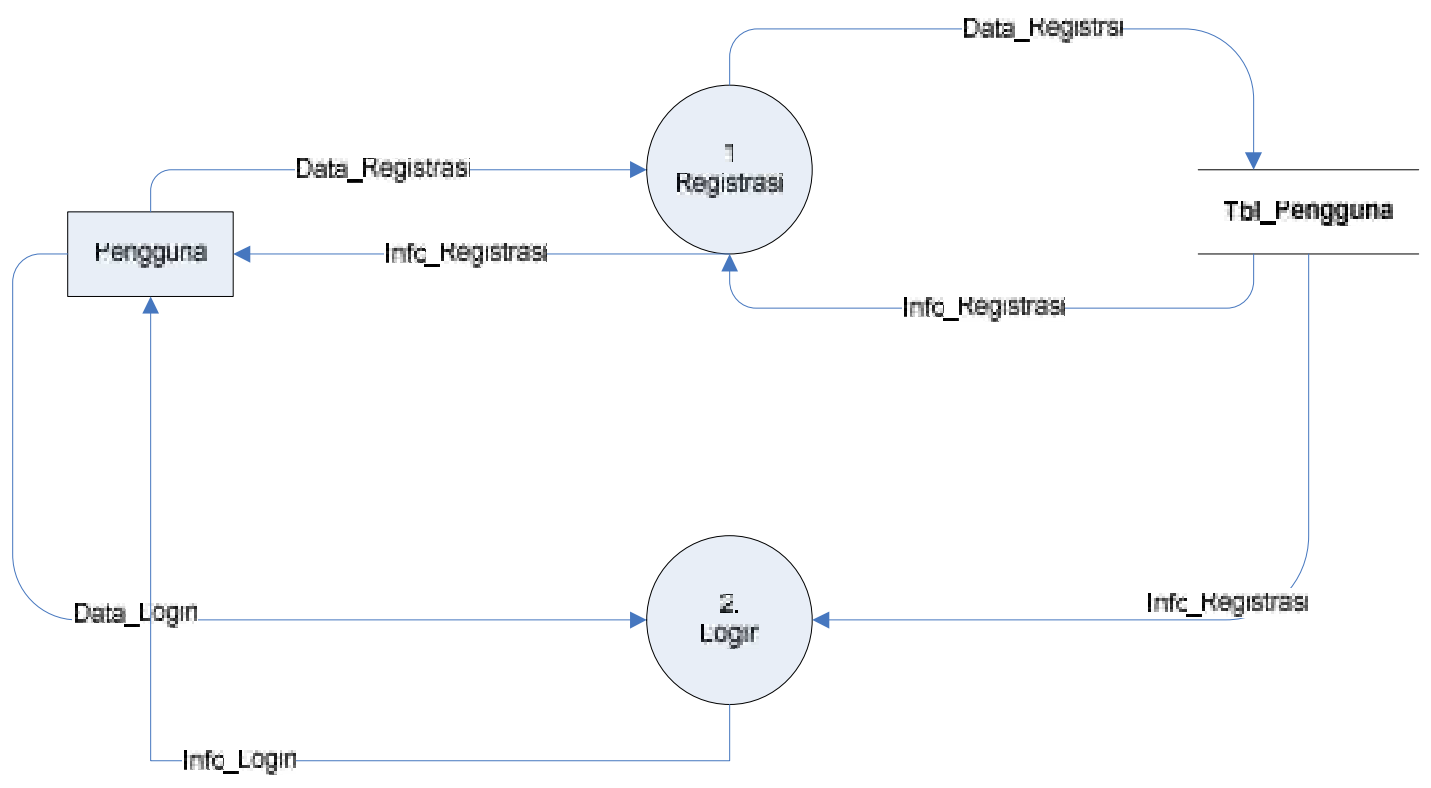

Gambar 4.7 Data Flow Diagram (DFD) Level 1

Gambar 4.3 merupakan DFD level 1 dari Diagram Kontek diatas yang dipecah menjadi 2 (dua) buah proses beserta aliran datanya. Untuk keterangan masing-masing dapat dilihat kamus data pada tabel 4.1 berikut ini.

\section{Tabel 4.1 Keterangan proses pada DFD level 1}

\begin{tabular}{|l|l|l|l|l|}
\hline No & \multicolumn{1}{|c|}{$\begin{array}{c}\text { Nama } \\
\text { Proses }\end{array}$} & \multicolumn{1}{|c|}{ Masukan } & Keluaran & \multicolumn{1}{c|}{ Deskripsi } \\
\hline 1 & Registrasi & - Input data registrasi & $\begin{array}{l}\text { - Status registrasi } \\
- \text { Status login }\end{array}$ & $\begin{array}{l}\text { Proses untuk } \\
\text { melakukan registrasi } \\
\text { account single sign-on }\end{array}$ \\
\hline 2 & Login & $\begin{array}{l}- \text { Input username } \\
- \text { Input Password } \\
\text { Input Autentikasi } \\
\text { Gambar }\end{array}$ & - Status login & $\begin{array}{l}\text { Proses untuk } \\
\text { melakukan login ke } \\
\text { dalam sistem single } \\
\text { sign-on }\end{array}$ \\
\hline
\end{tabular}




\subsubsection{Perancangan Tabel}

Berikut ini deskripsi perancangan tabel dalam database.

\section{Tabel Pengguna}

Nama : Pengguna

Deskripsi isi : Berisi data Pengguna

Primary key : id

\section{Tabel 4.2 Pengguna}

\begin{tabular}{|l|l|l|c|c|}
\hline \multicolumn{1}{|c|}{ Nama Field } & \multicolumn{1}{c|}{ Type dan Length } & Deskripsi & Null & Default \\
\hline id & int (10) & ID & No & \\
\hline nama & Varchar (50) & Nama & No & \\
\hline username & Varchar (30) & Username & No & \\
\hline password & Varchar (20) & Password & No & \\
\hline email & Varchar (30) & Email & No & \\
\hline image_auth & Text & Lokasi File Gambar & No & \\
\hline
\end{tabular}

\subsubsection{Perancangan Antar Muka}

Pada subbab ini akan ditampilkan rancangan antar muka sistem single signon. Sistem ini memiliki beberapa antar muka yaitu halaman pendaftaran pengguna, halaman login sistem single sign-on, halaman penyisipan gambar serta halaman utama atau halaman indeks.

\subsubsection{Perancangan Form Registrasi Pengguna}

Berikut ini adalah perancangan form registrasi calon member, yang terdiri dari Name, username, Your Email, password, Re-Enter Password, serta ImageAuthentication. Image Steganography merupakan link ke form steganografi. 


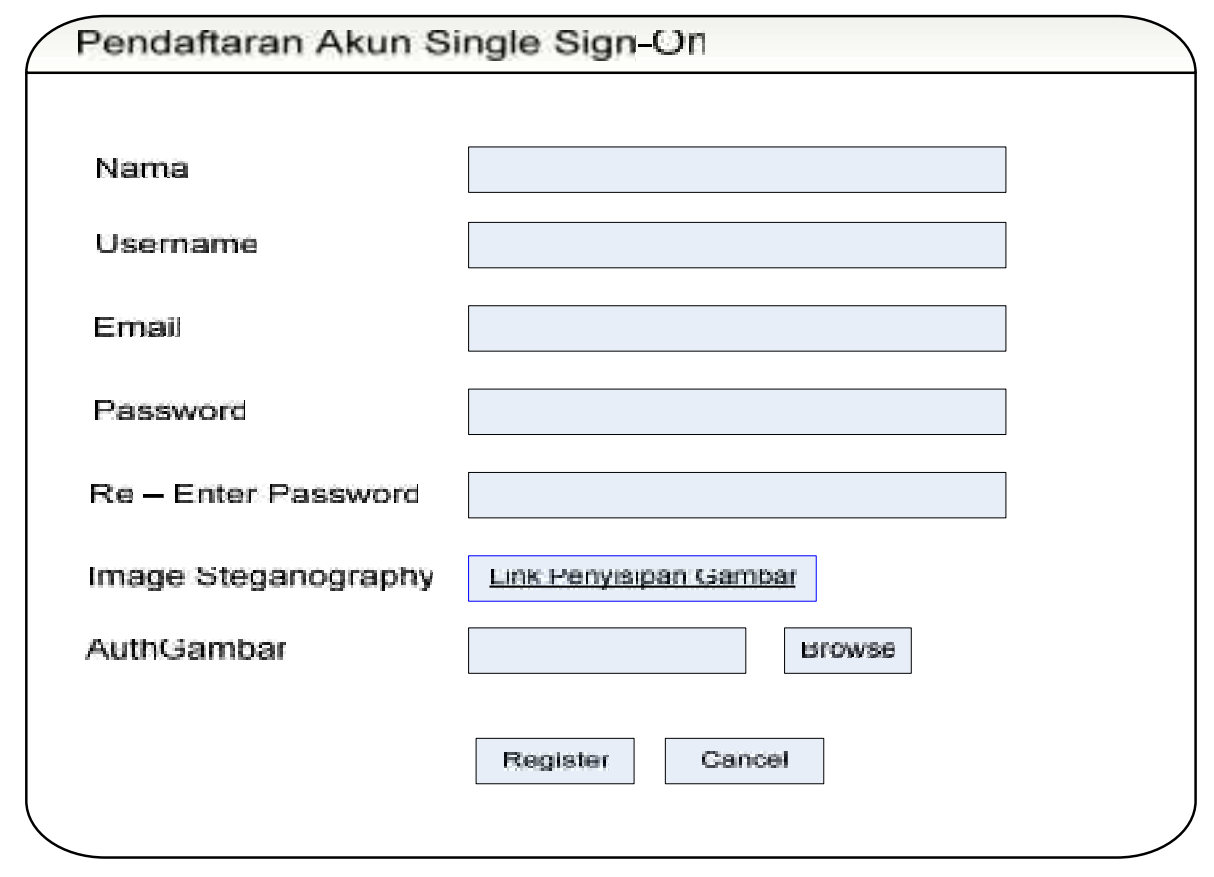

Gambar 4.8 Perancangan Form Registrasi

\subsubsection{Perancangan Form Steganografi}

Berikut adalah form steganografi, yang terdiri dari image atau gambar yang akan di disisipkan sebuah data atau file, serta hide file yaitu data yang akan disisipkan.

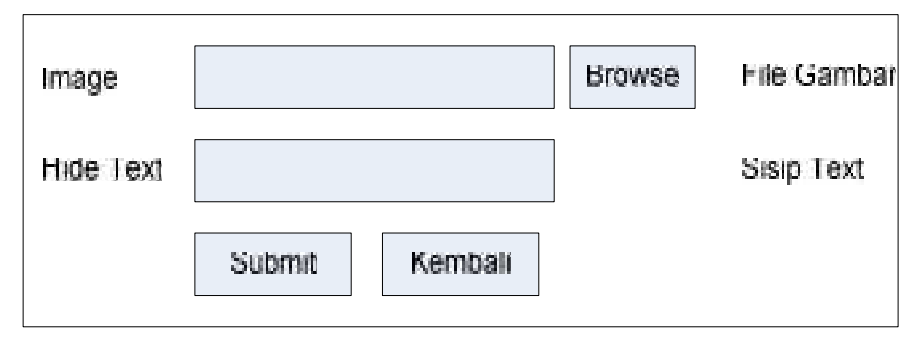

Gambar 4.9 Perancangan Form Steganografi 


\subsubsection{Perancangan Form Login Single Sign On}

Berikut ini adalah perancangan form login single sign-on yang terdiri dari username, password, serta autentikasi gambar.

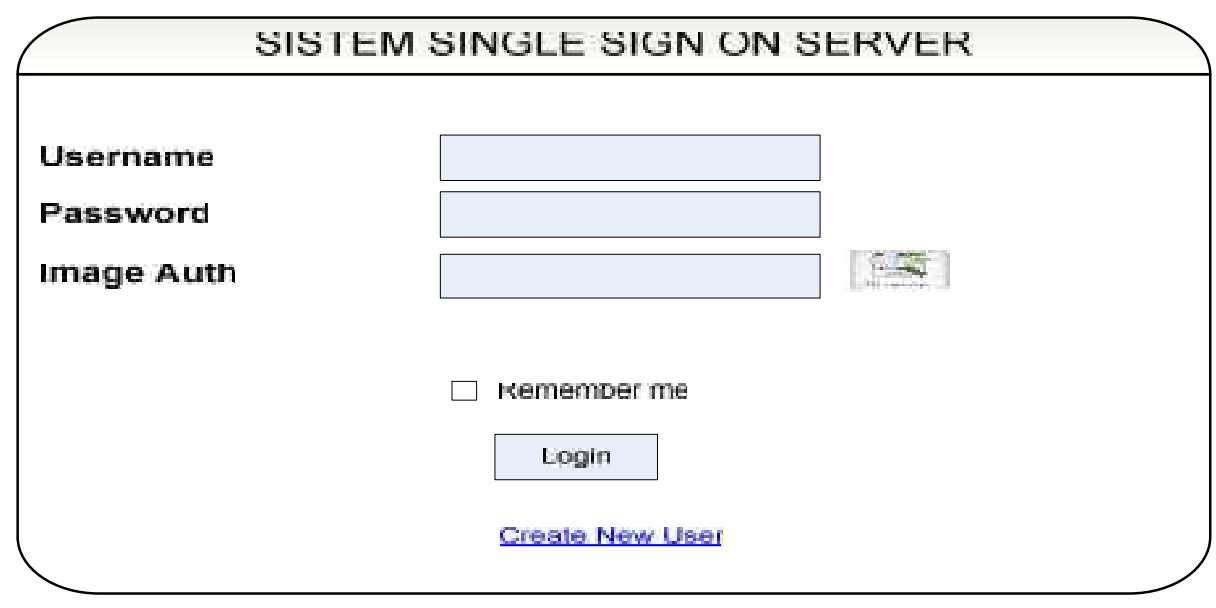

Gambar 4.10 Perancangan Form Login Single Sign-On

\subsubsection{Perancangan Halaman Utama}

Berikut adalah perancangan halaman utama atau index, jadi seorang member mengakses berbagai aplikasi web dari halaman tersebut. Pada halaman tersebut terdapat beberapa menu, diantaranya adalah Home, Aplikasi Web 1, Aplikasi Web 2, Aplikasi Web 3, dan About.

\section{SINGLE SIGN ON SYSTEM}

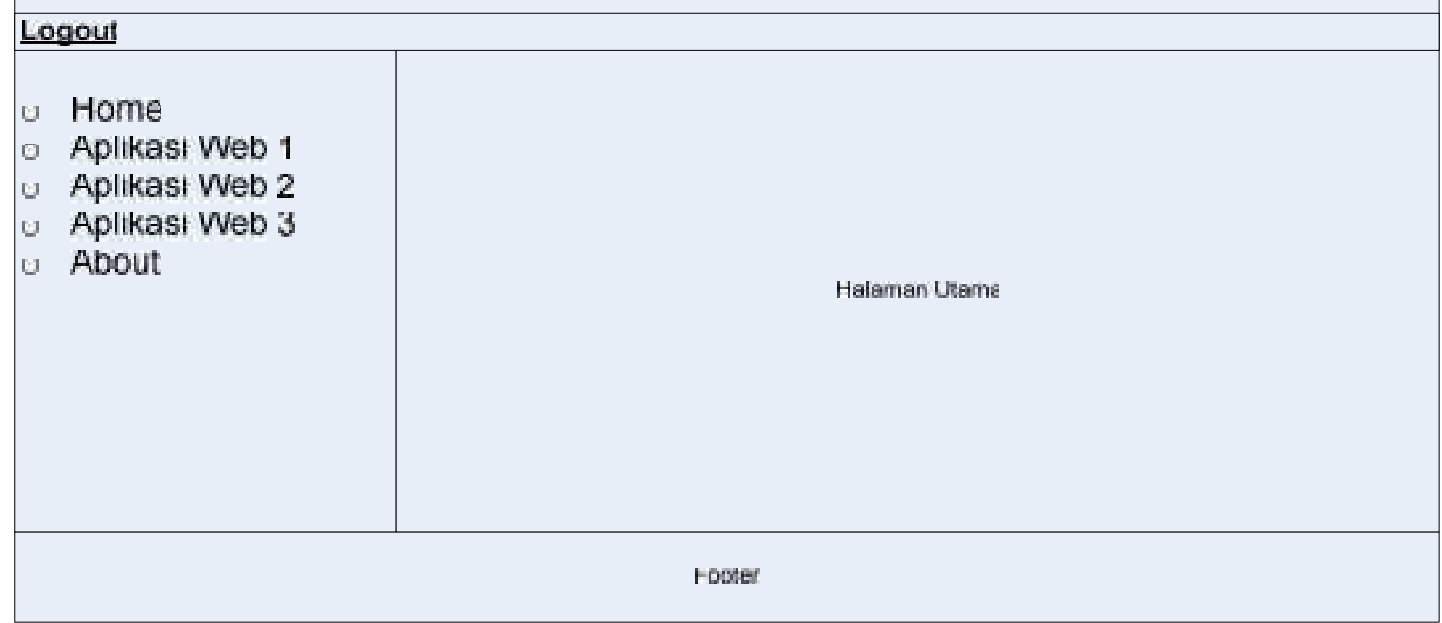

Gambar 4.11 Perancangan Halaman Utama 


\section{BAB V}

\section{IMPLEMENTASI DAN PENGUJIAN}

\subsection{Implementasi Sistem}

Implementasi merupakan tahap dimana sistem siap dioperasikan pada keadaaan yang sebenarnya, sehingga akan diketahui apakah sistem yang dibuat benar-benar dapat menghasilkan tujuan yang ingin dicapai.

\subsubsection{Lingkungan Implementasi}

Pada prinsipnya setiap desain sistem yang telah dirancang memerlukan sarana pendukung yaitu berupa peralatan-peralatan yang sangat berperan dalam menunjang penerapan sistem yang didesain terhadap pengolahan data.

Implementasi sistem single sign-on dilakukan dalam lingkungan perangkat keras komputer yang memiliki spesifikasi sebagai berikut :

1. Prosesor Intel Core i3 $2.40 \mathrm{GHz}$

2. Laptop DELL Inspiron 14" resolusi 1280 x 768 pixels

3. Memori $2 \mathrm{~GB}$

4. Harddisk $320 \mathrm{~GB}$

Sedangkan lingkungan pengembangan sistem tersebut memiliki spesifikasi perangkat lunak sebagai berikut :

1. Sistem Operasi Microsoft Windows XP Profesional SP 2

2. Adobe Photoshop 7.0

3. XAMPP for Windows 1.6.4 dengan PHP 5.2.4 dan Database 5.0.45

4. Web browser Mozilla Firefox 3.6

5. VMware Workstation 5.5.1

6. Notepad ++ v5.0.2 


\subsubsection{Batasan Implementasi}

Implementasi sistem single sign-on memiliki batasan sebagai berikut :

1. Implementasi dilakukan pada jaringan lokal, yaitu menggunakan aplikasi virtual VMWare.

2. Gambar yang digunakan sebagai autentikasi berformat PNG

\subsubsection{Teknis Implementasi Sistem Single Sign-On}

Teknik implementasi sistem dilakukan dengan beberapa tahapan sebagai berikut :

1. Implementasi pendaftaran akun single sign-on

Pada tahap implementasi ini dilakukan pendaftaran akun sistem single sign-on pada server single sign-on

2. Implementasi penyisipan gambar dengan Least Significant Bit

Pada tahap ini dilakukan penyisipan teks pada gambar, yang mana metode yang di gunakan menggunakan Least Significant Bit.

3. Implementasi login single sign-on

Tahap ini di lakukan login pada web portal, ketika member menekan tombol login maka member akan di arahkan ke halaman server single sign-on. Disini member memasukkan username, password serta gambar. Ketika member mengunjungi pada web portal yang lain maka sistem akan memeriksa apakah token cookie sudah ada, jika cookie-nya sudah ada maka secara otomatis sudah masuk login, member tidak perlu memasukkan username dan password lagi.

Sistem single sign-on diimplementasikan dengan menggunakan aplikasi Notepad ++ dengan bahasa pemrograman PHP. File implementasi sistem single sign-on dapat dilihat pada tabel 5.1 dan 5.2 . 
Tabel 5.1 Daftar File Server Single Sign-On

\begin{tabular}{|c|l|l|}
\hline No & Nama File & \multicolumn{1}{c|}{ Keterangan } \\
\hline 1 & Ssoserver.php & $\begin{array}{l}\text { File ini digunakan untuk melakukan proses autentikasi dengan } \\
\text { membuat token cookie, sehingga sistem bisa single sign-on }\end{array}$ \\
\hline 2 & Sso.php & $\begin{array}{l}\text { File ini merupakan file yang berada pada sisi client, dengan file ini, } \\
\text { ketika seorang melakukan login maka akan redirect ke server. }\end{array}$ \\
\hline 3 & Stego.php & $\begin{array}{l}\text { File ini digunakan untuk melakukan penyisipan gambar dengan } \\
\text { metode least significant bit. }\end{array}$ \\
\hline 4 & Index.php & File ini merupakan halaman antar muka sistem single sign-on \\
\hline 5 & Register.php & File ini digunakan untuk proses pendaftaran member \\
\hline 6 & Login.php & File ini merupakan halaman antarmuka login sistem single sign-on \\
\hline
\end{tabular}

Tabel 5.2 Daftar File Pada Client Web Portal

\begin{tabular}{|c|l|l|}
\hline No & Nama File & \multicolumn{1}{|c|}{ Keterangan } \\
\hline 2 & Sso.php & $\begin{array}{l}\text { File ini merupakan file yang berada pada sisi client, dengan file ini, } \\
\text { ketika seorang melakukan login maka akan redirect ke server. }\end{array}$ \\
\hline 4 & Index.php & File ini merupakan halaman antar muka web portal \\
\hline 6 & Login.php & File ini merupakan halaman antarmuka login sistem web portal \\
\hline
\end{tabular}

Implementasi secara rinci dapat dilihat pada lampiran B.

\subsection{Pengujian Sistem}

Pemrograman merupakan kegiatan penulisan program yang akan dieksekusi oleh komputer berdasarkan hasil dari analisa dan perancangan sistem. Sebelum program diimplementasikan, maka program tersebut harus bebas dari kesalahan. Pengujian program dilakukan untuk menemukan kesalahan-kesalahan yang mungkin terjadi.

\subsubsection{Lingkungan Pengujian Sistem}

Setelah tahap implementasi dilakukan maka tahap selanjutnya dengan pengujian dari implementasi yang telah dibuat. Tahap pengujian diperlukan agar dapat diketahui hasil dari program implementasi sistem. Program merupakan 
kegiatan penulisan kode program yang akan dieksekusi oleh komputer berdasarkan hasil dari analisis dan perancangan sistem.

Lingkungan pengujian yang digunakan memiliki spesifikasi perangkat keras komputer sebagai berikut :

1. Prosesor Intel Core i3 $2.40 \mathrm{GHz}$

2. Laptop DELL Inspiron 14" resolusi 1280 x 768 pixels

3. Memori 2 GB

4. Harddisk $320 \mathrm{~GB}$

Sedangkan lingkungan pengujian memiliki spesifikasi perangkat lunak sebagai berikut :

1. Sistem Operasi Microsoft Windows XP Profesional SP 2

2. XAMPP for Windows 1.6.4 dengan PHP 5.2.4 dan Database 5.0.45

3. Web browser Mozilla Firefox 3.6

4. VMware Workstation 5.5.1

5. Notepad ++ v5.0.2

Alamat DNS yang akan digunakan pada tugas akhir ini menggunakan alamat virtual host. Pada gambar 5.1 adalah arsitektur sistem single sign-on yang akan di ujikan :

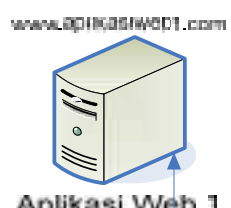

Aplikasi Web 1

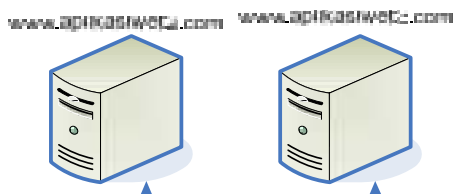

Aplikasi Wveb 2 Aplikasi Wreb 3
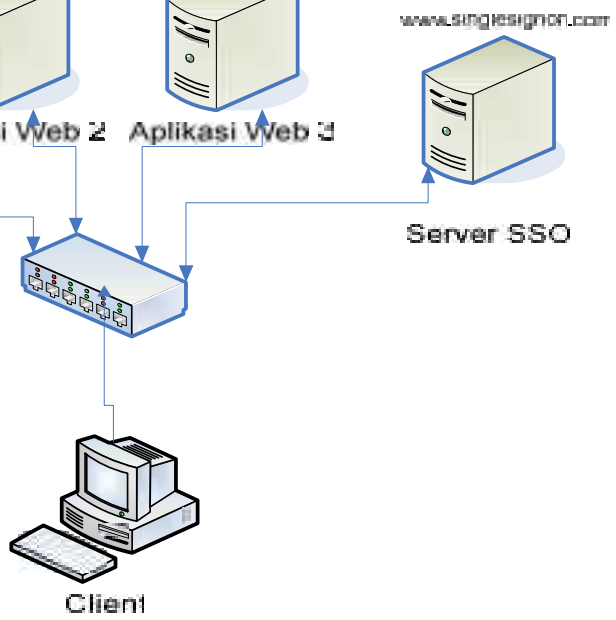

Server SSO

Gambar 5.1 Lingkungan Pengujian Sistem Single Sign-On 


\subsubsection{Pengujian Sistem Single Sign-On}

Pada pengujian aplikasi web sistem sigle sign-on, bahwa seorang pengguna mengakses kesalah satu dari aplikasi web, web kemudian akan diarahkan ke single sign-on server dan pengguna memasukkan credential-nya. Ketika pengguna berhasil login maka secara otomatis seluruh aplikasi web yang lain sudah terbuka dengan sendirinya tanpa memasukkan credential lagi.

Proses pengujiannya adalah sebagai berikut :

1. Member melakukan login pada server single sign-on dengan memasukkan username, password dan gambar.

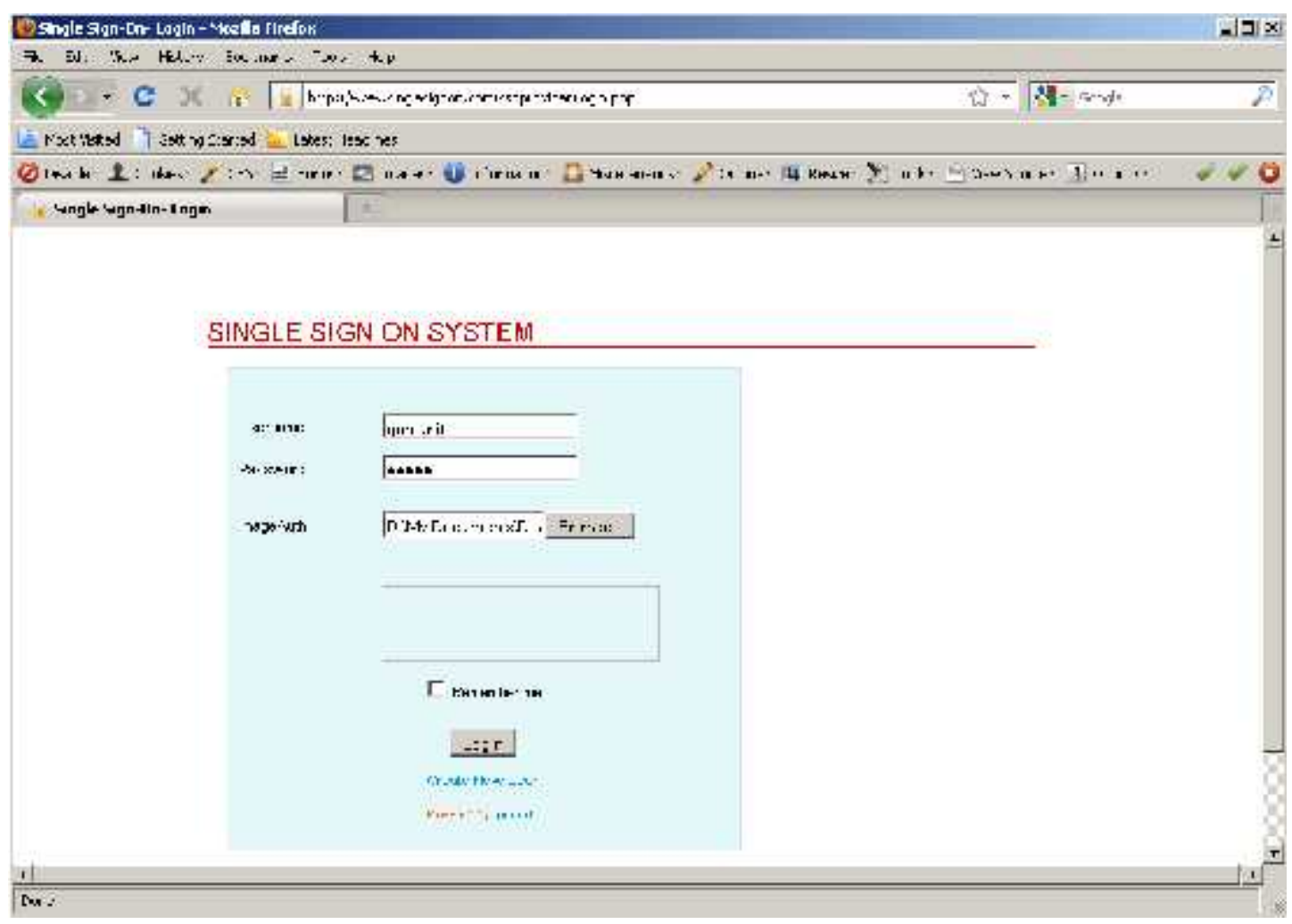

Gambar 5.2 Halaman Login Sistem Single Sign-On

Pengujian sistem single sign-on dengan memasukkan username, password serta gambar, jika username, password dan gambar sesuai dengan di server maka login telah berhasil, dan langsung menuju ke halaman utama web portal. 
2. Member berhasil melakukan login dan memasuki halaman web portal

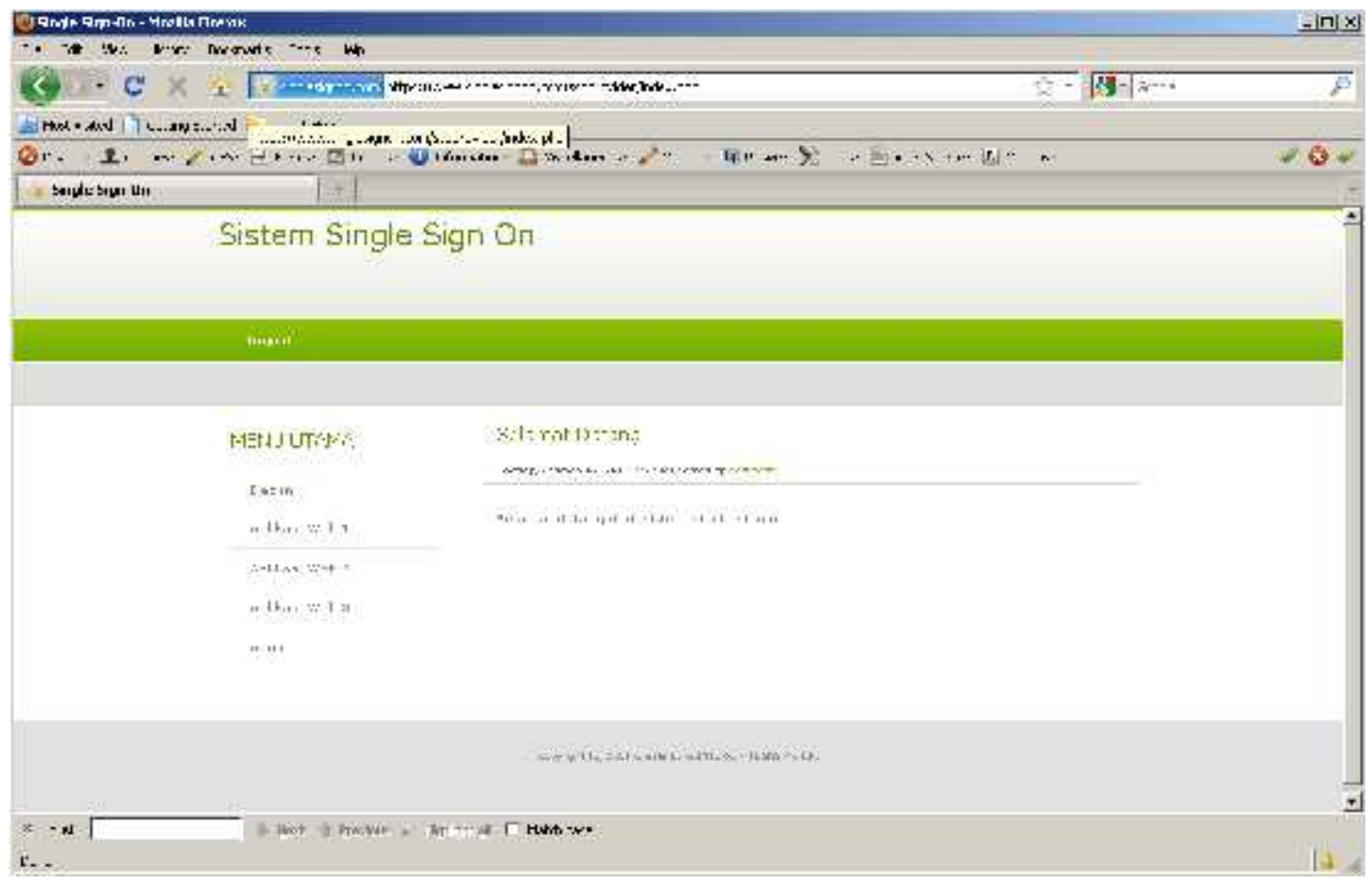

Gambar 5.3 Halaman Utama Sistem Single Sign-On

3. Member mengakses Aplikasi Web 1 dan berhasil melakukan login tanpa memasukkan credential.

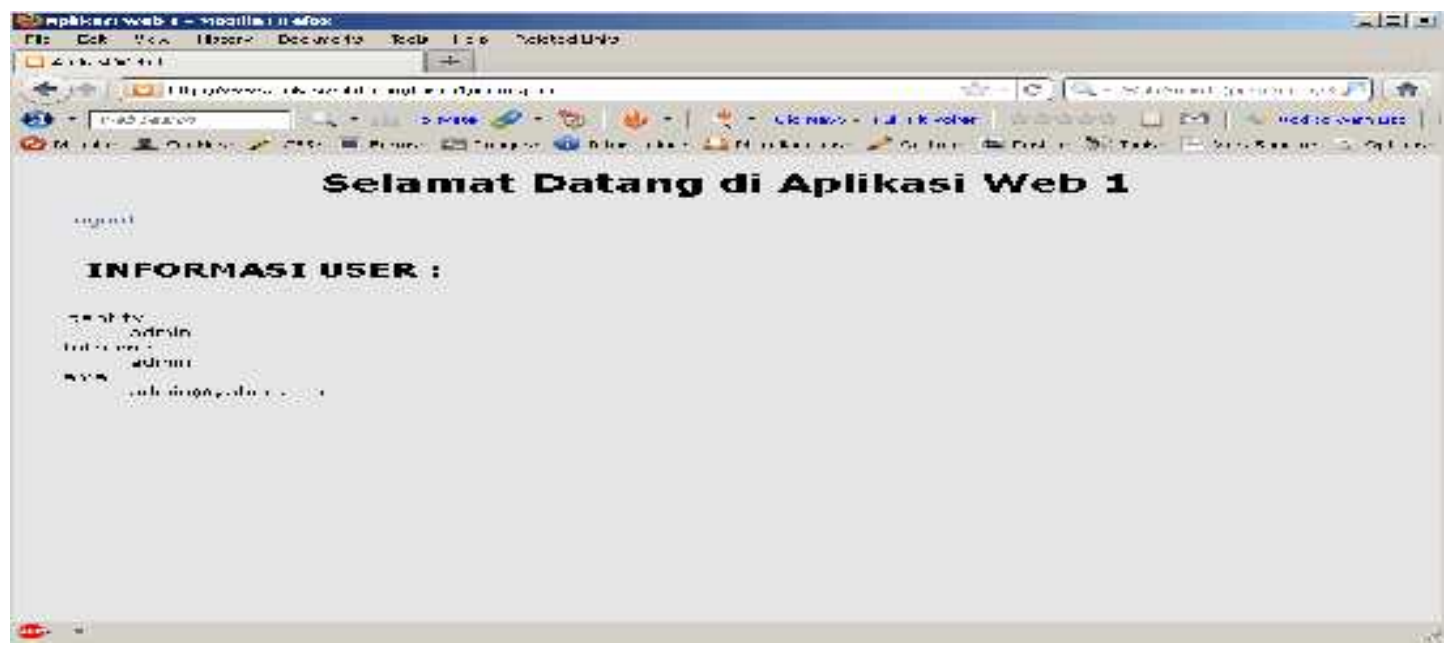

Gambar 5.4 Aplikasi Web 1 
Ketika member mengakses aplikasi web yang lain maka secara otomatis web sudah dalam keadaan login, tanpa harus melakukan login untuk kedua kalinya dan begitu pula selanjutnya. Begitu pula sebaliknya, ketika seorang member melakukan logout dari salah satu situs web maka secara otomatis situs yang lain akan logout dengan sendirinya tanpa perlu menekan tombol logout kedua kalinya. Pengujian sistem secara rinci dilihat pada lampiran C.

\subsubsection{Pengujian Berdasarkan Prosedur Sistem Single Sign-On}

Pada tahap ini dilakukan pengujian terhadap sistem single sign-on yang telah dibangun, apakah sudah memenuhi beberapa prosedur-prosedur dalam membangun sistem single sign-on. Beberapa prosedur yang akan diujikan adalah Authentication, Strong Authentication dan Authorization.

\subsubsection{Pengujian Authentication}

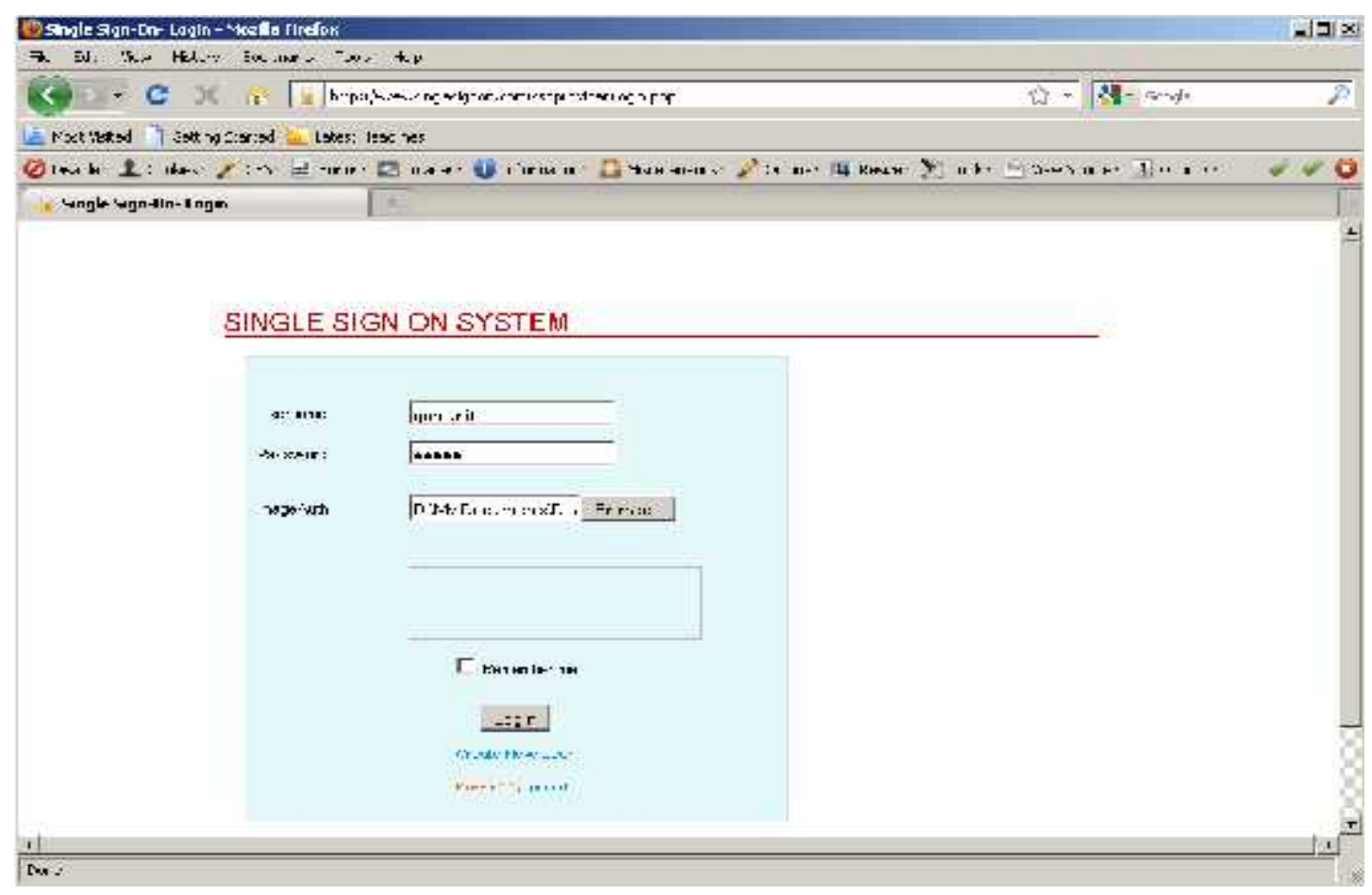

Gambar 5.5 Pengujian Authentication 
Dari gambar 5.5 dapat dilihat bahwa pengujian authentication yaitu dengan menggunakan username dan password telah berhasil diujikan.

\subsubsection{Pengujian Strong Authentication}

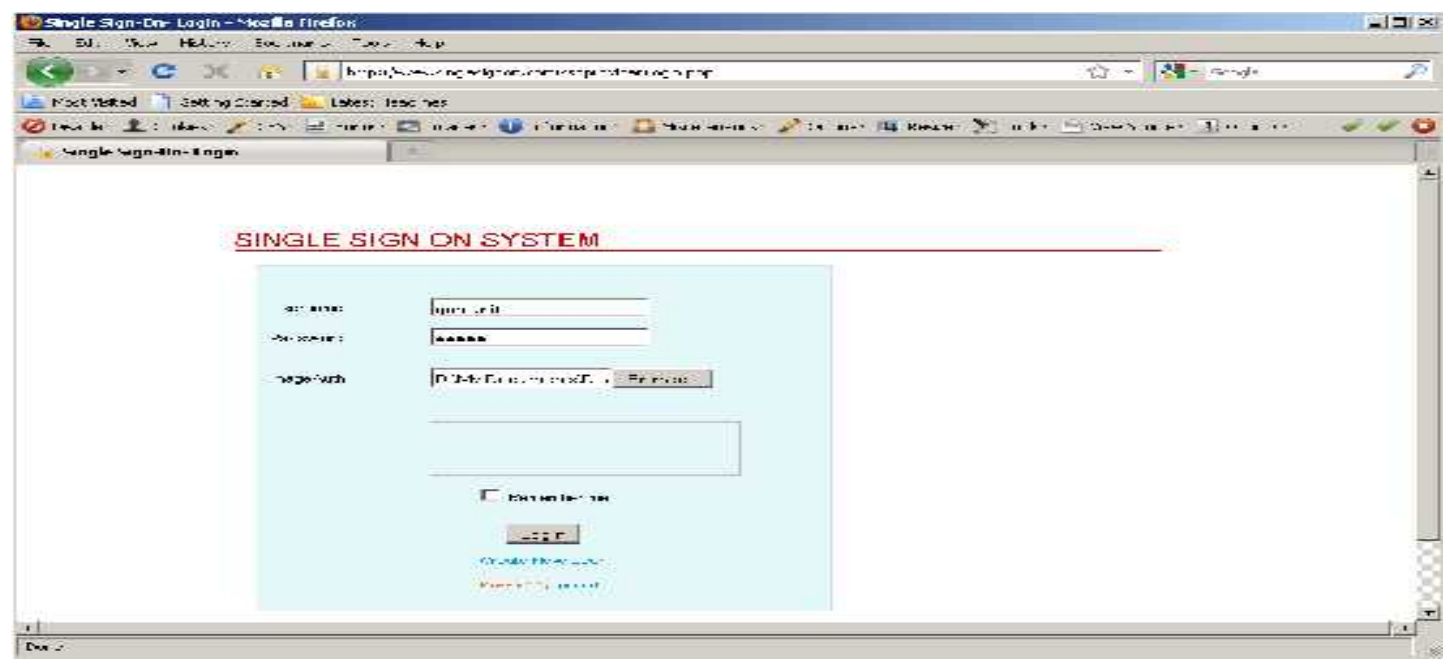

Gambar 5.6 Pengujian Strong Authentication

Dari gambar 5.6 dapat dilihat bahwa pengujian strong authentication yaitu dengan menggunakan autentikasi gambar telah berhasil diujikan

\subsubsection{Pengujian Authorization}

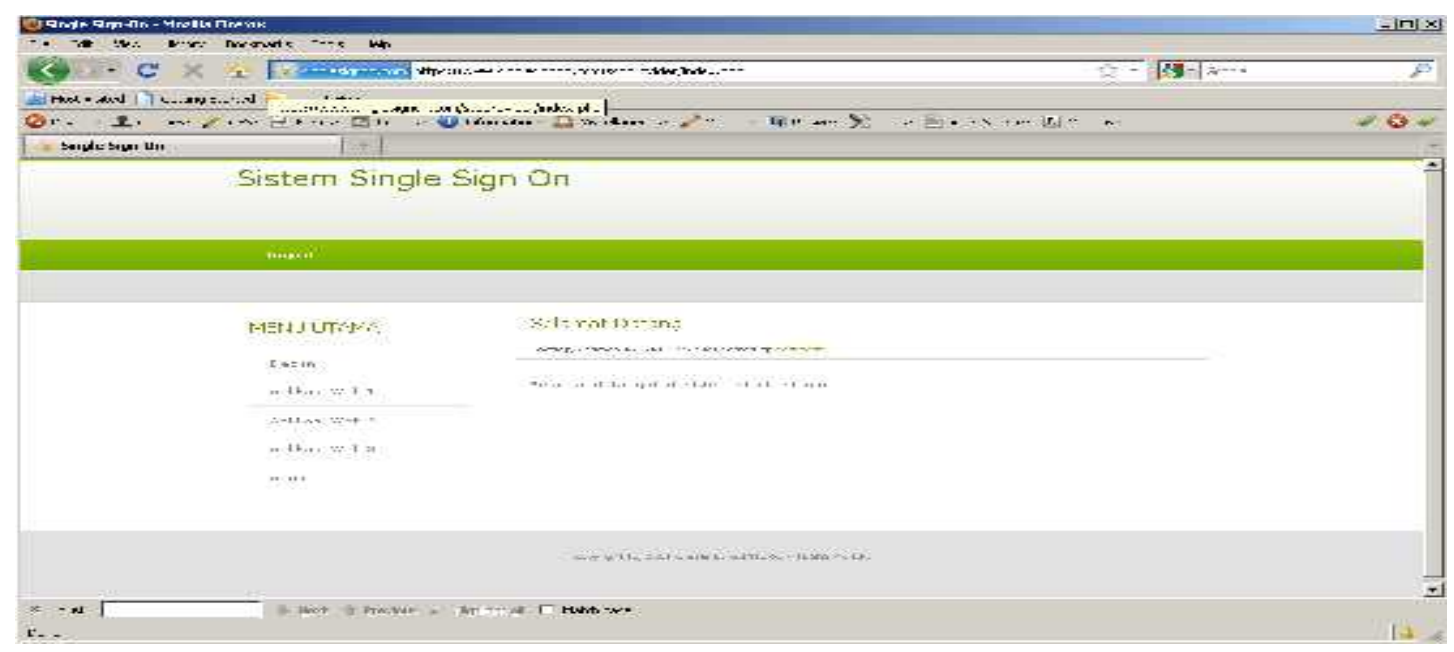

Gambar 5.7 Pengujian Authorization 


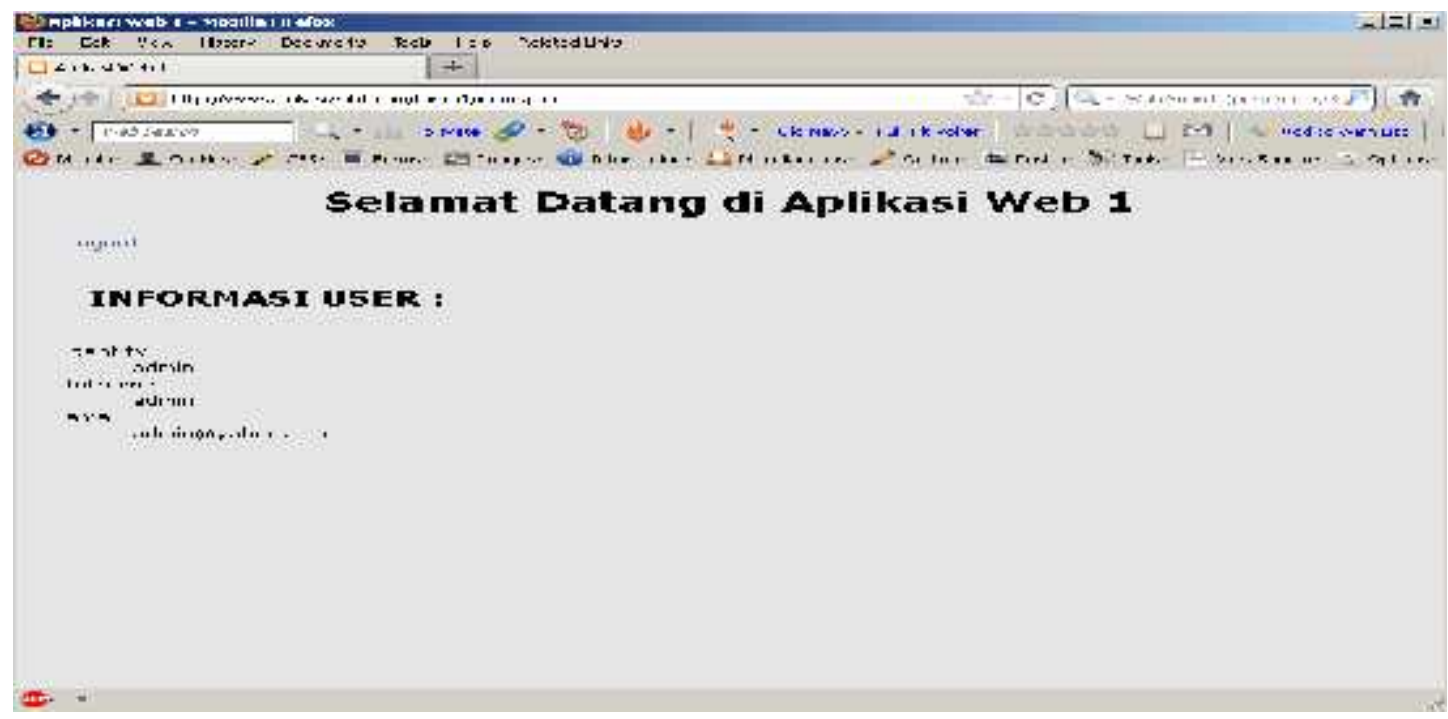

\section{Gambar 5.8 Pengujian Authorization Aplikasi Web 1}

Dari gambar 5.7 dan 5.8 dapat dilihat bahwa sistem single sign-on yang dibangun dapat melakukan otorisasi, ketika aplikasi web 1 dibuka maka secara otomatis sudah login, tanpa harus melakukan autentikasi. Begitu juga dengan aplikasi web yang lain.

\subsubsection{Pengujian Keamanan Sistem Single Sign-On}

Pada tahap ini di lakukan pengujian terhadap keamanan sistem sigle sign-on yang telah di bangun dengan menggunakan aplikasi keylogger, aplikasi sniffer. Aplikasi keylogger dan sniffer yang akan digunakan pada pengujian ini adalah sebagai berikut :

Tabel 5.3 Spesifikasi Aplikasi Pengujian

\begin{tabular}{|l|c|c|}
\hline Spesifikasi & KGB Employee Monitor & Wireshark \\
\hline Version & 4.5 .4 & 1.2 .10 \\
\hline Jenis Aplikasi & Keylogger & Sniffer \\
\hline Size & $5.2 \mathrm{MB}$ & $7.5 \mathrm{MB}$ \\
\hline
\end{tabular}




\section{Pengujian Sistem Tanpa Single Sign-On dengan Aplikasi Keylogger}

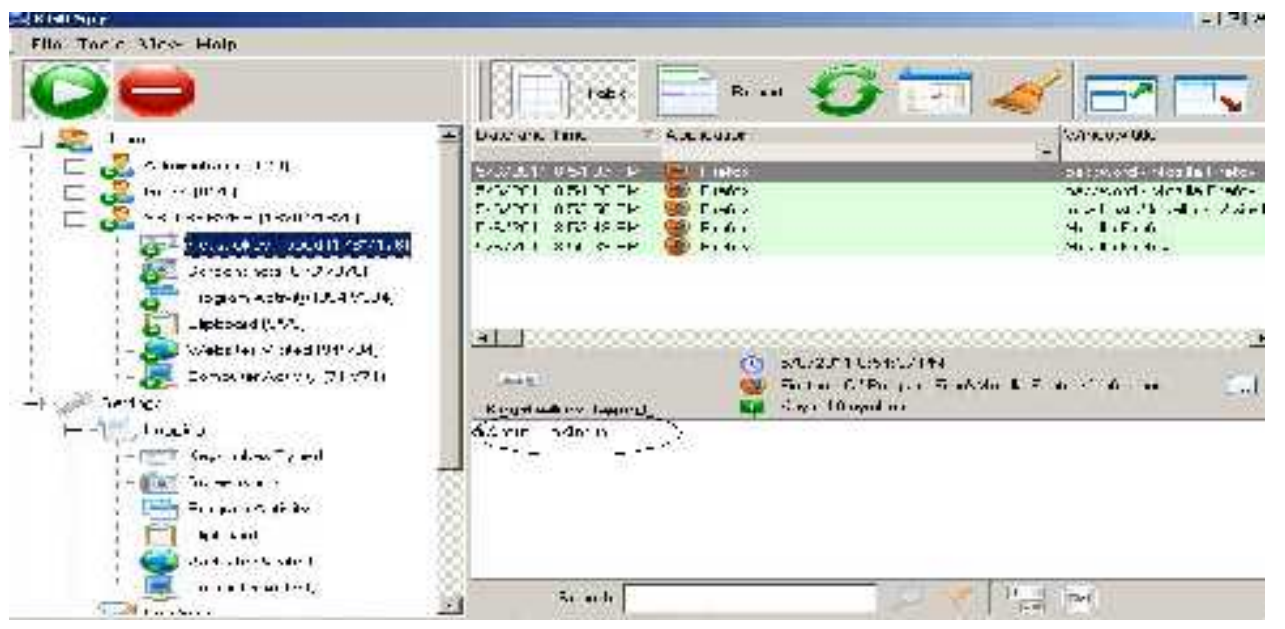

Gambar 5.9 Pengujian Sistem Tanpa Single Sign-On dengan Keylogger

Dari gambar 5.9 dapat terlihat bahwa autentikasi berbasis teks yaitu username dan password ter-capture oleh aplikasi Keylogger.

2. Pengujian Sistem Single Sign-On dengan aplikasi keylogger KGB Employee Monitor

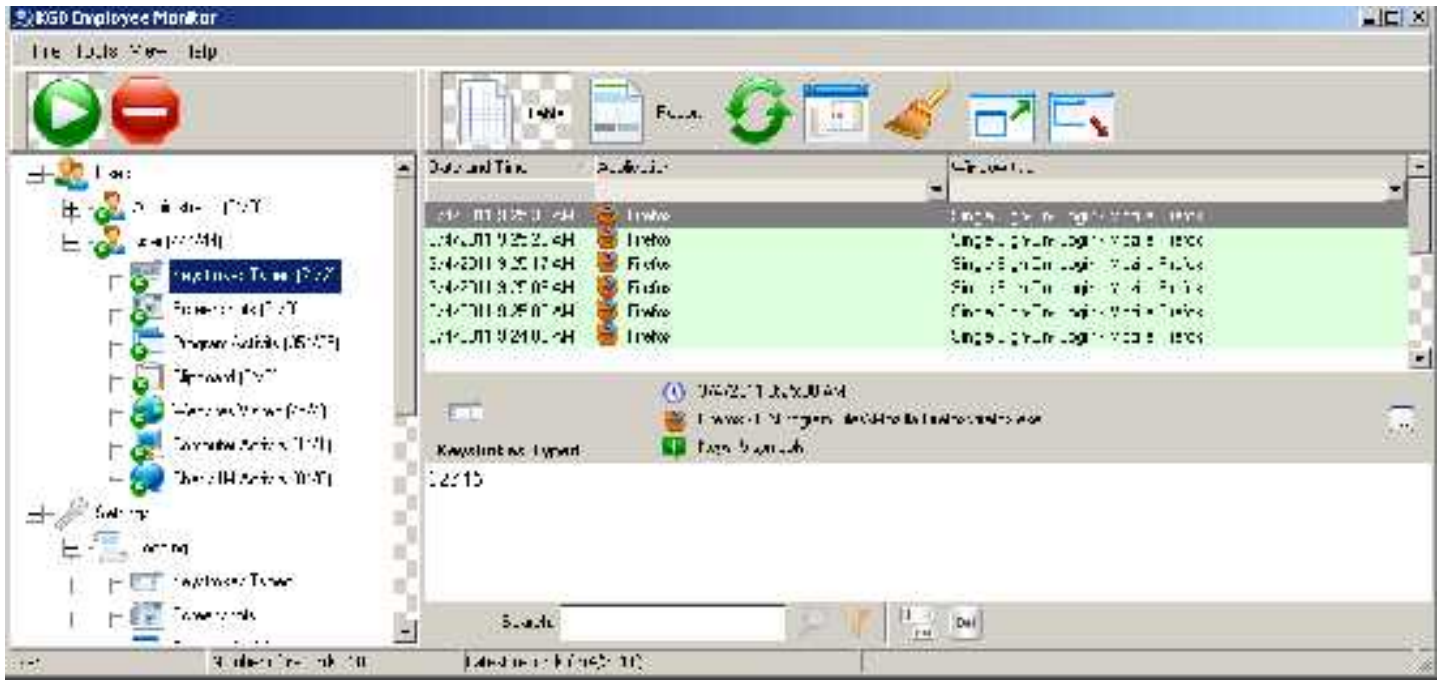

Gambar 5.10 Pengujian dengan Aplikasi Keylogger 1 


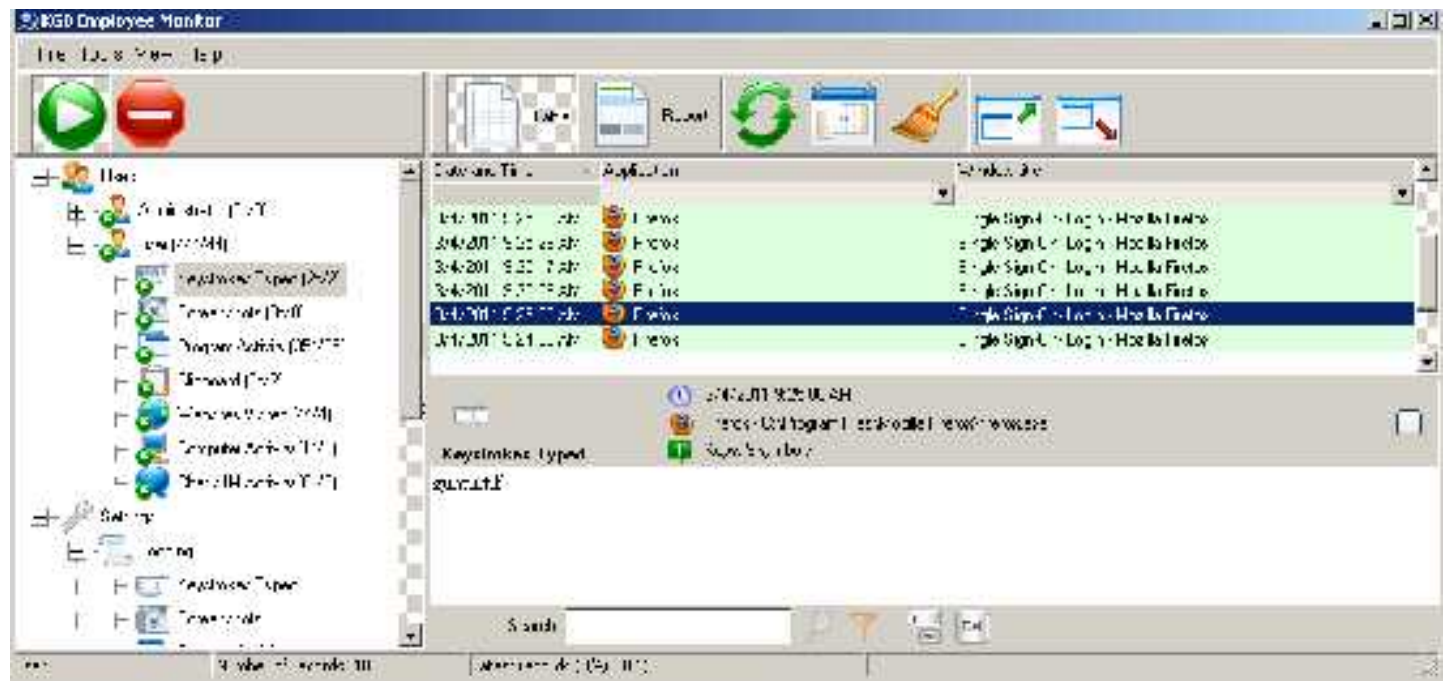

Gambar 5.11 Pengujian dengan Aplikasi Keylogger 2

Pada pengujian gambar 5.10 dan gambar 5.11 dilakukan login dengan mengetikkan username, password serta gambar, dengan menggunakan aplikasi keylogger tersebut menunjukkan bahwa gambar tidak ter-capture oleh aplikasi keylogger.

\section{Pengujian Sistem Tanpa Single Sign-On dengan Aplikasi Wireshark}

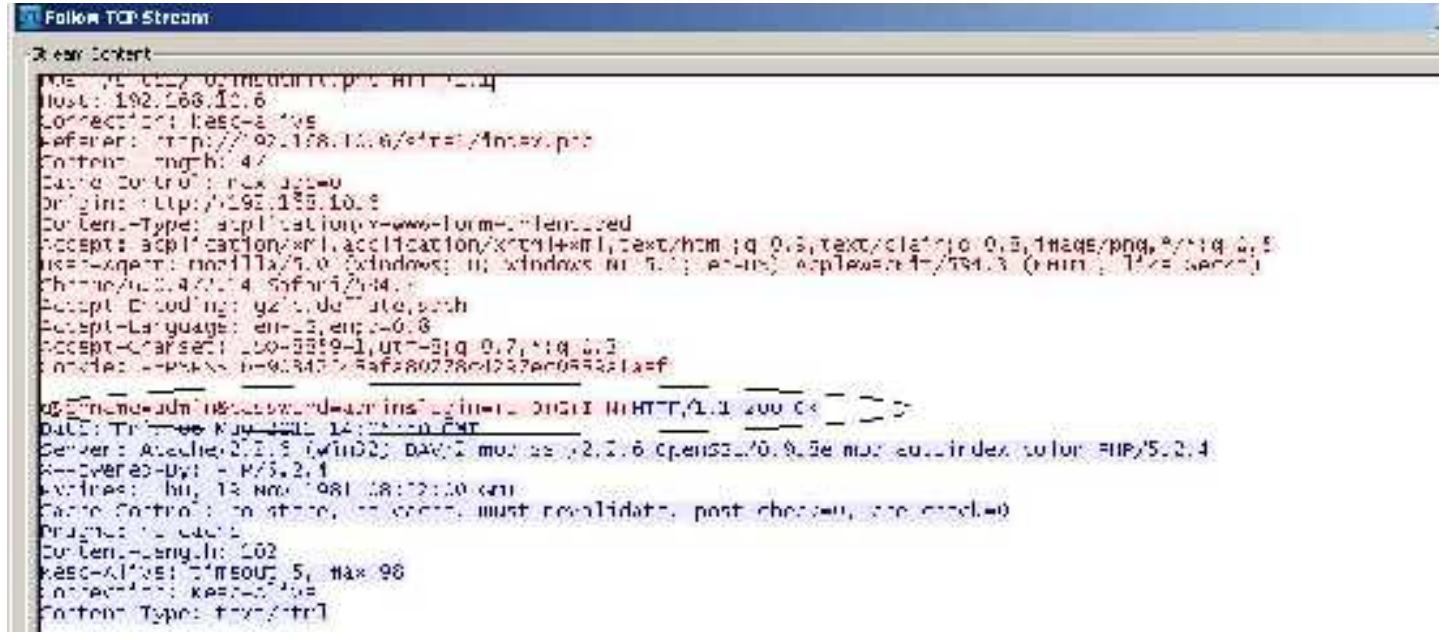

Gambar 5.12 Pengujian Sistem Tanpa Single Sign-On dengan Wireshark 
Dari gambar 5.12 dapat terlihat bahwa autentikasi berbasis teks yaitu username dan password ter-capture oleh aplikasi Wireshark.

\section{Pengujian Single Sign-On dengan aplikasi Wireshark}

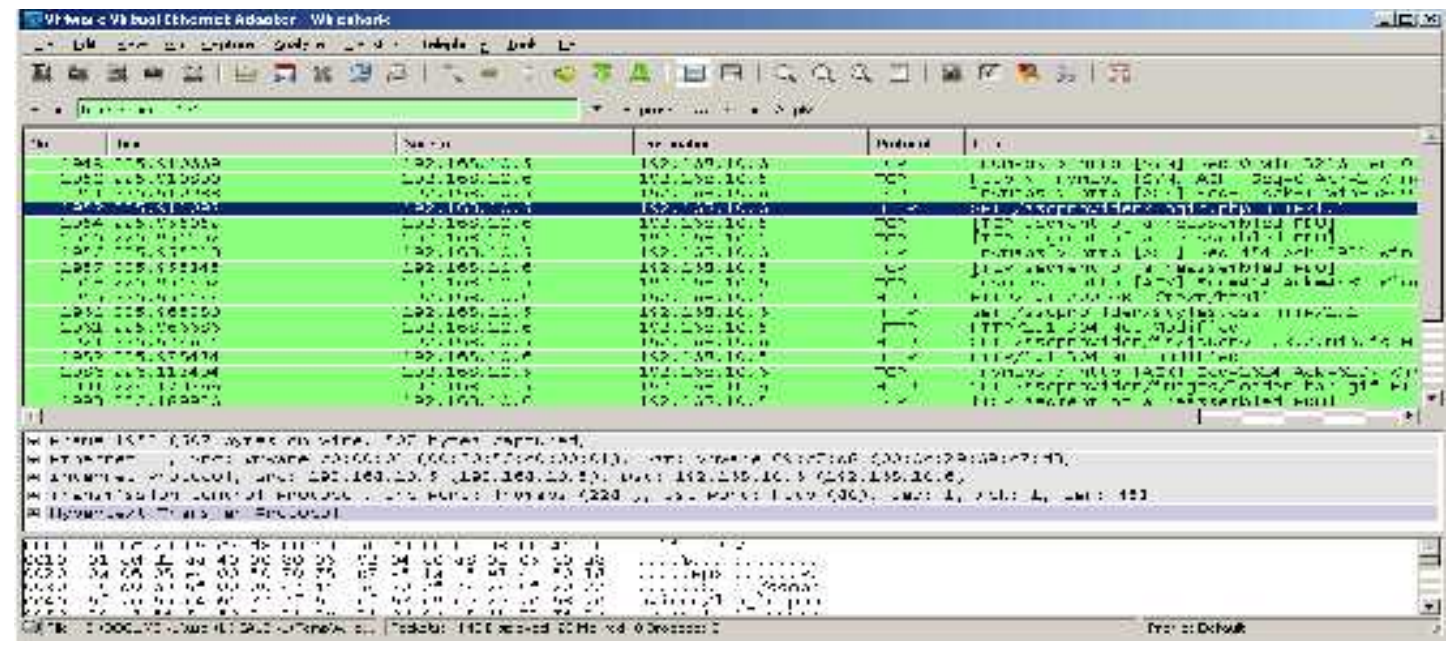

Gambar 5.13 Pengujian dengan Aplikasi Wireshark

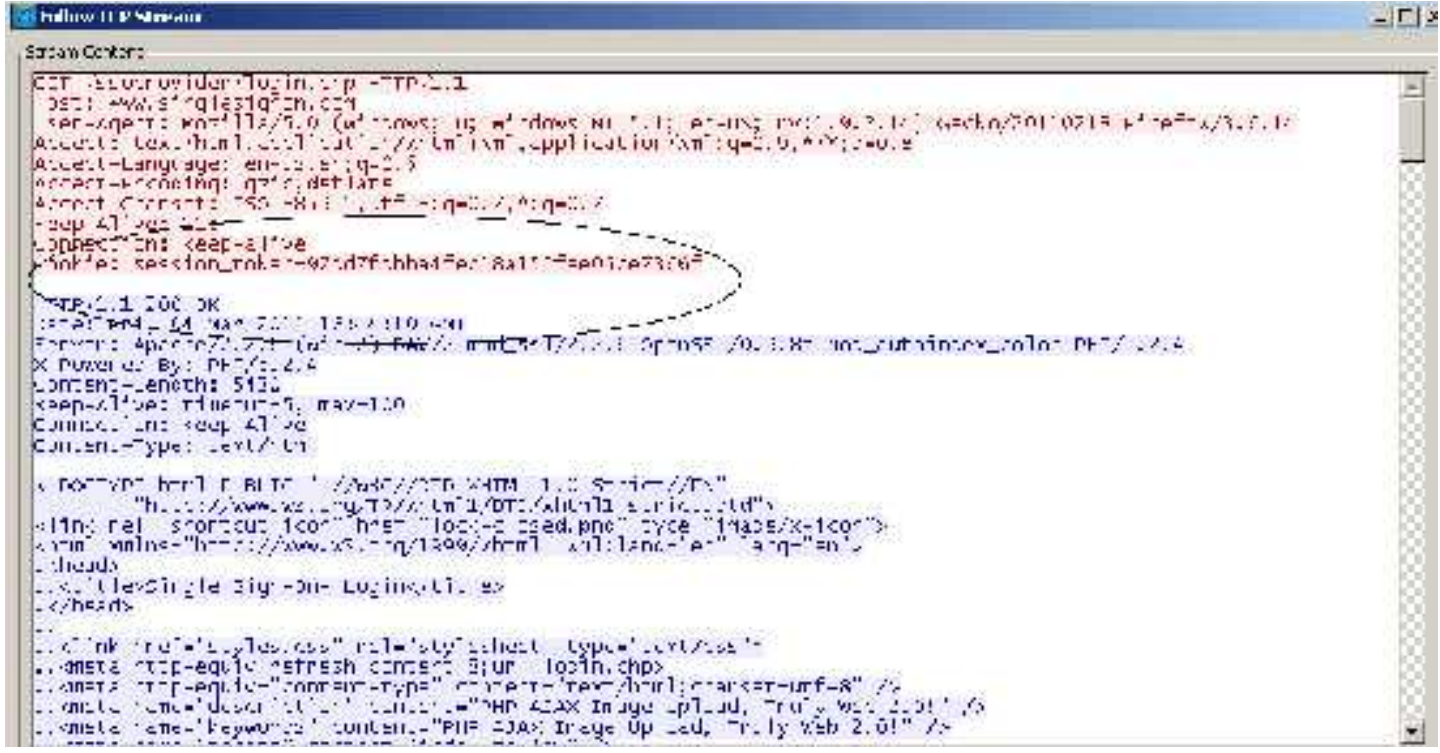

Gambar 5.14 Capture Sistem Single Sign-on dengan Wireshark

Pada pengujian gambar 5.14, member mengakses sistem single sign-on server dan melakukan login dengan memasukkan username, password serta gambar, dengan 
menggunakan aplikasi tersebut menunjukkan bahwa username, password dan gambar tidak ter-capture oleh aplikasi wireshark .

\subsubsection{Kesimpulan Pengujian}

Secara umum, hasil pengujian yang diperoleh adalah sebagai berikut :

1. Sistem Single Sign-On yang telah dibangun dapat berjalan dengan baik, seorang member tidak perlu login untuk kedua kalinya, member cukup sekali login.

2. Pengujian berdasarkan prosedur sistem single sign-on telah berhasil diujikan.

3. Autentikasi dengan menggunakan gambar tidak ter-capture oleh aplikasi keylogger, sehingga dapat menambah keamanan sistem single sign-on.

4. Seluruh aplikasi yang di implementasikan dapat berjalan. 


\section{BAB VI \\ PENUTUP}

Pada bab ini akan dipaparkan kesimpulan yang didapat dari pelaksanaan Tugas Akhir. Selain itu, disampaikan beberapa saran yang berguna untuk kelanjutan pengembangan topik yang diambil.

\subsection{Kesimpulan}

Beberapa hal yang dapat disimpulkan dari pelaksanaan tugas akhir ini adalah :

1. Berhasil membangun sebuah sistem single sign-on berbasis web, dimana seorang user hanya sekali memasukkan credential untuk beberapa situs web tanpa harus memasukkan username dan password untuk kedua kalinya.

2. Autentikasi login menggunakan gambar merupakan salah satu solusi untuk keamanan sistem login terutama sistem single sign-on, karena sesuai dengan pengujian, file gambar tidak ter-capture oleh aplikasi keylogger.

3. Steganografi Least Significant Bit dapat diimplementasikan dengan baik untuk melakukan pengamanan gambar yang digunakan sebagai autentikasi login.

4. Sistem autentikasi menggunakan gambar pada aplikasi single sign-on hanya digunakan pada aspek non-repudiation.

5. Sistem autentikasi gambar menggunakan format PNG.

6. SSL diperlukan oleh sistem single sign-on dalam melakukan enkripsi session. Sehingga dapat meminimalisir terjadinya proses pencurian password member.

\subsection{Saran}

Saran-saran yang berkaitan dengan pelaksanaan tugas akhir ini adalah :

1. Aplikasi sistem Single Sign-On ini perlu di uji pada kasus yang lebih besar dan lingkungan yang bervariasi agar dapat diketahui kinerja aplikasi. Pada Tugas Akhir ini, sistem Single Sign-On hanya diuji pada jaringan virtual atau jaringan komputer lokal. 
2. Database yang digunakan dalam aplikasi ini masih terlalu sederhana jika dibandingkan dengan aplikasi yang lain. Sehingga perlu dilakukan konfigurasi lebih lanjut untuk menghadapi masalah ini.

3. Untuk meningkatkan keamanan gambar sebagai autentikasi, dapat menggunakan teknik keamanan gambar yang lain. 


\section{DAFTAR PUSTAKA}

Alkhatib Ghazi, dan Rine David, " Integrated Approaches in Information Technology and Web Engineering: Advancing Organizational Knowledge Sharing”, IGI Global, 2009.

Ardagna Claudio Agostino, Frati Fulvio, Gianini Gabriele, "Open Source in WebBased Applications : A Case Study on Single Sign-On". Chapter VI, IGI Global, 2009.

Ariyus Dony, “Computer Security”, Penerbit Andi Yogyakarta. 2006.

Bettini, C., Jajodia, S., Sean Wang, X., \& Wijesekera, D. Provisions and obligations in policy management and security applications. In Proceedings of the 28th VLDB Conference, HongKong, China. 2002.

Bulger Brad, Greenspan Jay, and Wall David, "MySQL/PHP Database Applications, Second Edition", Wiley Publishing, Inc., Indianapolis, Indiana. 2004.

Hursti Jani, “ Single Sign-On.”, Department of Computer Science Helsinki University of Technology, 1997.

Nitin, Sehgal Kumar Vivek, Chauhan Sigh Durg, Sood Munish, and Hastir Vikas, "Image Based Authentication System with Sign-In Seal" Proceedings of the World Congress on Engineering and Computer Science, 2008.

Pashalidis and C. J. Mitchell, "A Taxonomy of Single Sign-On Systems, in Information Security and Privacy, $8^{\text {th }}$ Australian Conference, ACISP 2003, Wollong, Australia, July 9-11, 2003, Proceedings, ser. Lectures Notes In Computer Science, R. Safavi-Naini and J. Seberry, Eds., vol 2727. Springerverlag, pp 249-264. July 2003 
Kanda, “Integrasi Single Sign-On OpenID pada Website berbasis PHP”, [Online] Available http://www.kandar.info, diakses 10 Januari 2011

Shawn Riley, “Why You Should Consider a Single Sign On Product in Health Care”, [Online] Available http://www.healthtechnica.com, diakses 09 Desember 2010 , “Single Sign-On”, [Online] Available http://www.id.wikipedia.org/, diakses 20 November 2010 